\title{
MANEJO DA IRRIGAÇÃO NA CULTURA DA ROSEIRA CULTIVADA EM AMBIENTE PROTEGIDO
}

\author{
EDIVALDO CASARINI
}

Engenheiro Agrônomo

Orientador: Prof. Dr. MARCOS VINÍCIUS FOLEGATTI

Dissertação apresentada à Escola Superior de Agricultura "Luiz de Queiroz", Universidade de São Paulo, para obtenção do título de Mestre em Agronomia, Área de Concentração: Irrigação e Drenagem.

P I R A C I C A B A

Estado de São Paulo - Brasil

Maio - 2000 


\section{Errata}

Página 4, última linha: substituir por: "pois as rosas apresentam alta qualidade."

Página 9, primeiro parágrafo-última linha: após umidade relativa substituir o sinal ">" por "<".

Página 20, segundo parágrafo, segunda linha: onde se lê germinadas substituir por geminadas.

Página 20, terceiro parágrafo, última linha: após a palavra mais profunda substituir ponto final por vírgula e completar, "classificando o solo como Latossolo Vermelho-Amarelo Orto."

Página 22, primeiro parágrafo, última linha: Substituir "Tabela 2" por "Tabela 3."

Página 29, segundo parágrafo, quinta linha: antes das palavras "da roseira" incluir "da haste".

Página 34, penúltima linha: incluir a letra "F" após a palavra "teste".

Página 35, terceiro parágrafo: Substituí-lo por: "Estes resultados permitem observar uma relação entre o aumento do comprimento das hastes de acordo com o aumento da lâmina aplicada. Chimonidou-Pavlidou (1998) trabalhando com diferentes freqüências de ịrrigação $(0,2$, 3 e 6 dias) na cultura da rosa cultivada em vasos com $0,30 \mathrm{~m}$ de diâmetro e aplicando a mesma lâmina de irrigação determinada pelo tanque Classe A durante nove meses, observou que o comprimento das hastes foram significativamente menores, quando a planta foi submetida a um intervalo de irrigação de 6 dias durante o verão.

Página 50, Tabela 10: incluir após potencial matricial "(-kPa)" e após IAF " $\left(\mathrm{m}^{2} / \mathrm{m}^{2}\right)$.

Página 57, Referências bibliográficas, incluir entre as citações de Caballero et al. e De Graf, CALVACHE, A.M.; REICHARDT, K.; MALAVOLTA, E.; BACCHI, O.O.S. Efeito da deficiência hídrica e da adubação nitrogenada na produtividade e na eficiência do uso de água em uma cultura do feijão. Scientia Agrícola, v.54, n.3, p.232-240, 1997.

CHIMONIDOU-PAVLIDOU, D. Yield and quality of rose 'Madelon' as affected by four irrigation and three shading regimes. Acta Horticulturae, n.458, p. $95-102,1998$. 
Dados Internacionais de Catalogaçāo na Publicaçāo (CIP) DIVISÃO DE BIBLIOTECA E DOCUMENTAÇÃO - Campus "Luiz de Queiroz"/USP

Casarini, Edivaldo Manejo da irrigação na cultura da roseira cultivada em ambiente protegido / Edivaldo Casarini. - - Piracicaba, 2000. 66 p. : il.

Dissertação (mestrado) - - Escola Superior de Agricultura Luiz de Queiroz, 2000. Bibliografia.

1. Estufa 2. Irrigação 3. Manejo 4. Rosa 5. Tanque evaporimétrico I. Título

$$
\text { CDD } 635.933 \frac{3}{372}
$$




\section{A meus pais, Orlando e Maria}

pelo grande incentivo e dedicação em todas

as fases de minha vida.

MINHA HOMENAGEM

E

AGRADECIMENTO

\section{A DEUS,}

pela fé que me faz crescer a cada dia.

AGRADEÇO 


\section{AGRADECIMENTOS}

Ao Prof. Dr. Marcos Vinícius Folegatti, por toda orientação e confiança durante o curso;

Ao Departamento de Engenharia Rural da Escola Superior de Agricultura "Luiz de Queiroz" (ESALQ/USP) pela oportunidade de cursar o mestrado;

À Coordenação de Aperfeiçoamento de Pessoal de Nível Superior (CAPES), pela concessão da bolsa de estudos;

A Alice Noemi Aranda Franco, pelos momentos de alegria e companheirismo durante o curso de pós-graduação;

Àos amigos Roberto Shimokuma e Edson Shimokuma de Atibaia, pela área de rosas para a condução do experimento;

Ao amigo Jorge Alberto Junqueira Americano, pela amizade que sempre nos acompanhou;

À empresa IrrigaFértil de Atibaia, pela doação do sistema de irrigação para execução do ensaio;

A Roberto Jun Takane, pela oportunidade de aumentar os meus horizontes;

A Gilmar Batista Grigolon, do Laboratório de Física de Solos, pela ajuda prestada com as análises de solos.

Enfim, a todos os meus amigos do curso de Pós-Graduação, que me ajudaram e que sempre estiveram firmes em seus propósitos de fornecer sua contribuição para a agricultura brasileira. 


\section{SUMÁRIO}

Pág.



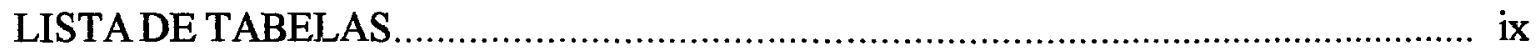

RESUMO

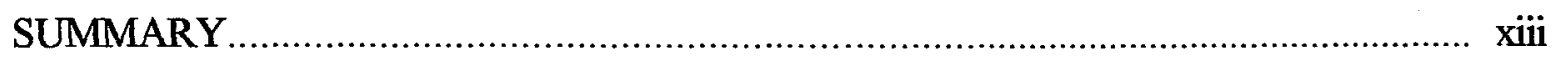

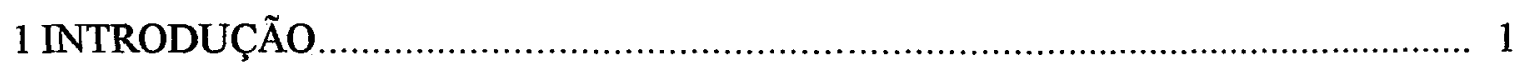

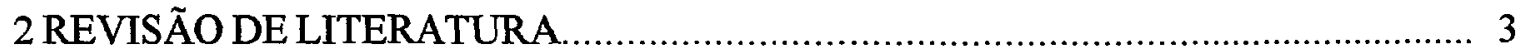

2.1. A cultura da rosa........................................................................... 3



2.1.2.Importância econômica................................................................. 4

2.1.3. Características da planta................................................................. 5

2.1.4. Efeito da temperatura e da umidade relativa do ar e radiação solar



2.2. Efeito do ambiente protegido na temperatura e umidade relativa

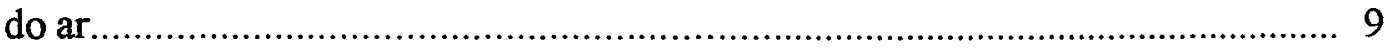

2.3. Evapotranspiração...................................................................... 11

2.4. Importância da água para a cultura da rosa......................................... 13

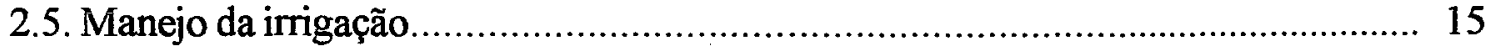

2.5.1. Coeficiente de cultivo................................................................. 17

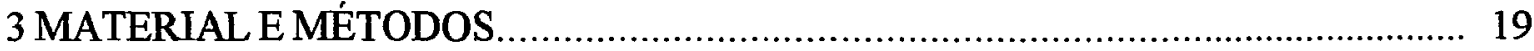



3.2. Determinação da curva característica de água no solo................................. 21

3.3. Sistema de irrigação................................................................... 22



3.5 Manejo da irrigação e fertirrigação ............................................................. 26

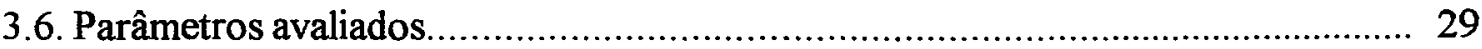


3.6.1. Produção de hastes comerciais............................................................... 29

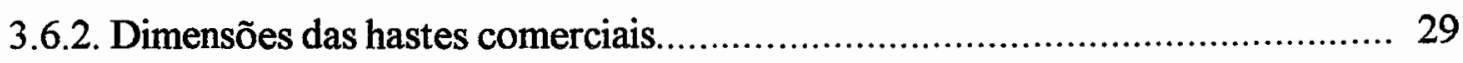

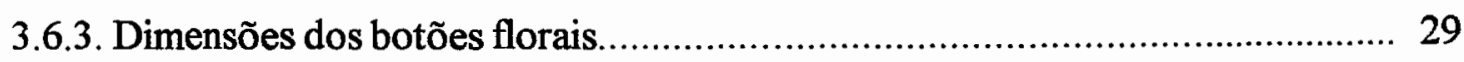

3.6.4. Massa fresca dos botões........................................................................ 30

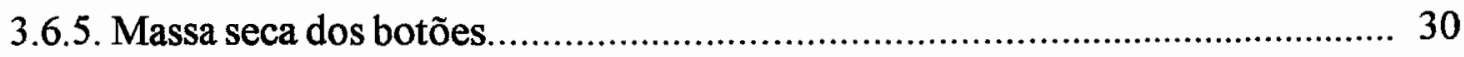

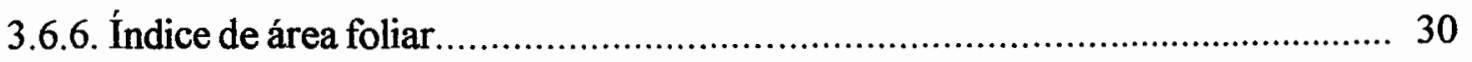

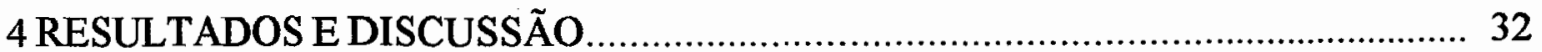

4.1. Evaporação do tanque evaporimétrico reduzido............................................. 32

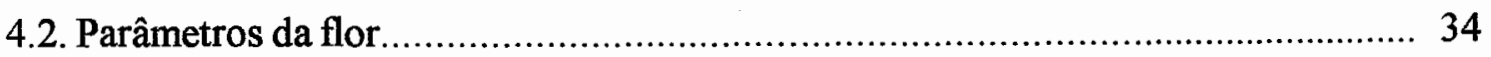

4.2.1. Comprimento e diâmetro das hastes......................................................... 34

4.2.2. Comprimento e diâmetro dos botões florais................................................ 37

4.2.3. Massa fresca e massa seca dos botões florais........................................... 39

4.3 Produtividade de rosas....................................................................... 41

4.4 Eficiência do uso da água pela cultura da rosa................................................. 43

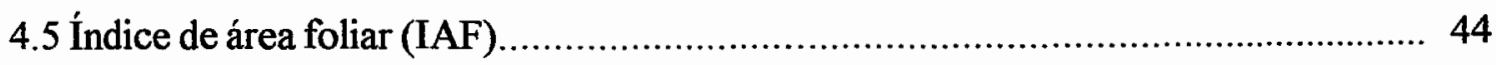

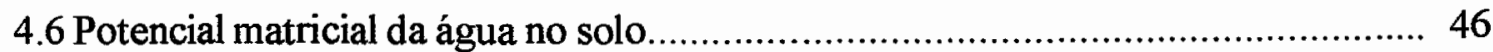

4.6.1 Potencial matricial versus IAF............................................................ 50

4.6.2 Potencial matricial versus produtividade de hastes....................................... 53

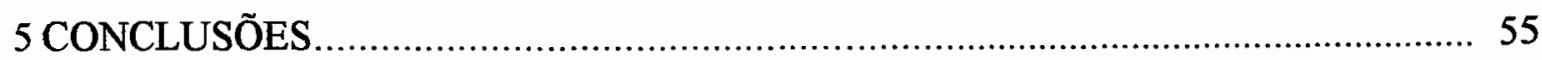

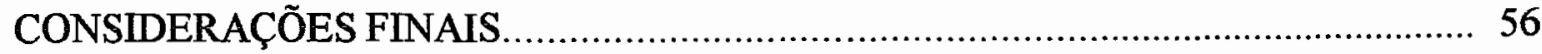

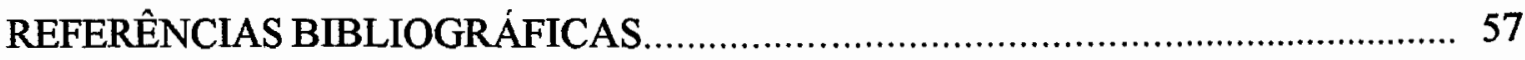

APÊNDICE 


\section{LISTA DE FIGURAS}

Pág.

1 Cultivar Osiana (Champgne) utilizada no experimento............. 19

2 Curva característica de retenção da água no solo para as

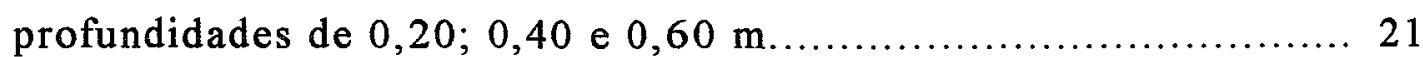

3 Vista geral do experimento com o sistema de irrigação com registro de esfera (a), tanque evaporimétrico reduzido (b), tensímetro digital de punção (c) e a bateria de tensiômetros instalados à 0,$10 ; 0,30$ e $0,50 \mathrm{~m}$ de profundidade $(\mathrm{d}) \ldots \ldots \ldots \ldots \ldots . \ldots 23$

4 Croqui da área experimental....................................... 25

5 Lâminas acumuladas aplicadas nos tratamentos T25, T50, T75, T100 e T125 durante o experimento

6 Evaporação diária medida no tanque evaporimétrico reduzido durante o experimento............................................ 33

7 Relação entre fração de evaporação do tanque reduzido e comprimento médio das hastes florais............................... 36

8 Relação entre fração de evaporação do tanque reduzido e o diâmetro das hastes florais............................................ 37

9 Relação entre a fração de evaporação do tanque reduzido e o comprimento dos botões florais..................................... 38

10 Relação entre a fração de evaporação do tanque reduzido e o diâmetro dos botões florais........................................ 39

11 Relação entre a fração de evaporação do tanque reduzido e a massa fresca dos botões florais... 
12 Relação entre a fração de evaporação do tanque reduzido e a massa seca dos botões florais

13 Relação entre a fração de evaporação do tanque reduzido e a 42 produtividade das hastes florais

14 Variação do IAF em função das frações de evaporação do tanque reduzido.

15 Relação entre IAF e produtividade de haste/parcela.

16 Variação do potencial matricial de água no solo em função das frações de evaporação do tanque reduzido na profundidade de $0,10 \mathrm{~m}$

17 Variação do potencial matricial de água no solo em função das frações de evaporação do tanque reduzido na profundidade de $0,30 \mathrm{~m}$

18 Variação do potencial matricial de água no solo em função das frações de evaporação do tanque reduzido na profundidade de $0,50 \mathrm{~m}$.

19 Relação entre potencial matricial de água no solo e IAF na profundidade de $0,10 \mathrm{~m}$.

20 Relação entre potencial matricial de água no solo e IAF na profundidade de $0,30 \mathrm{~m}$.

21 Relação entre potencial matricial de água no solo e o IAF na profundidade de $0,50 \mathrm{~m}$

22 Produtividade da roseira em função do potencial matricial para

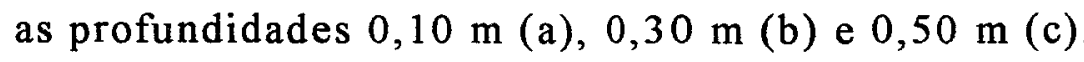




\section{LISTA DE TABELAS}

Pág.

1 Análise granulométrica do solo na área experimental............. 20

2 Parâmetros do modelo de van Genuchten para as profundidades de



3 Valores de umidade volumétrica do solo nas tensões de $30,0 \mathrm{kPa}$

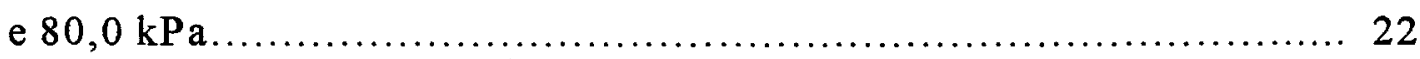

4.a Concentrações de macronutrientes na fórmula A................. 28

4.b Concentrações de micronutrientes na fórmula A.................. 28

5 Concetração de macronutrientes na fórmula B...................... 28

6 Valores médios observados para comprimento das hastes (C.H.), diâmetro das hastes (D.H.), comprimento dos botões (C.B.), diâmetro dos botões (D.B.), massa fresca dos botões florais (M.F.B.) e massa seca dos botões florais (M.S.B.).................. 34

7 Valores médios do índice de área foliar (IAF) e da produtividade em cada tratamento............................................... 42

8 Eficiência do uso da água na cultura da rosa........................ 44

9 Valores máximos, mínimos e médios do potencial matricial $(\mathrm{kPa})$ de água no solo para cada tratamento............................. 49

10 Valores médios de potencial matricial de água no solo e IAF para cada fração de evaporação de água no solo................... 50

11 Quadro de análise de variança e regressão para comprimento das hastes florais ...................................................... 64

12 Quadro de análise de variança e regressão para diâmetro das hastes florais 
Pág.

13 Quadro de análise de variança e regressão para comprimento dos

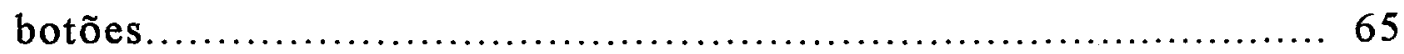

14 Quadro de análise de variança e regressão para diâmetro dos

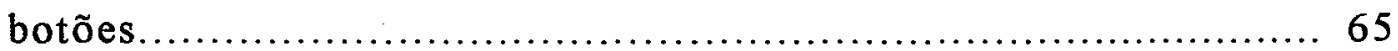

15 Quadro de análise de variança e regressão para massa fresca dos



16 Quadro de análise de variança e regressão para massa seca dos






\title{
MANEJO DA IRRIGAÇÃO NA CULTURA DA ROSEIRA CULTIVADA EM AMBIENTE PROTEGIDO
}

\author{
RESUMO
}

Com o objetivo de avaliar a qualidade das hastes e dos botões florais da roseira, cv Osiana e sua produtividade em ambiente protegido, foi conduzido um experimento em uma área de produção comercial de rosas no município de Atibaia - SP durante o período de 14/10/99 a 14/12/99. Instalou-se um tanque evaporimétrico reduzido com as dimensões de $0,60 \mathrm{~m}$ de diâmetro e $0,25 \mathrm{~m}$ de altura no centro de um ambiente protegido com cobertura plástica com $39,0 \mathrm{~m}$ de comprimento e 6,5 m de largura. $O$ delineamento experimental utilizado foi o de blocos casualizados com cinco tratamentos e cinco repetições, onde foram aplicadas lâminas de irrigação correspondentes às frações de 25 , $50,75,100$ e $125 \%$ da evaporação do tanque reduzido, com turno de rega de dois dias. Os parâmetros avaliados nas hastes e botões florais foram o comprimento e diâmetro das hastes, comprimento, diâmetro, massa fresca e massa seca dos botões florais, índice de área foliar e produtividade da roseira cultivada em ambiente protegido.

Os resultados obtidos neste trabalho mostraram que não houve diferença significativa entre os tratamentos para os parâmetros avaliados, entretanto a qualidade das hastes e botões florais, o IAF e a produtividade de rosas aumentaram de acordo com o aumento da lâmina de irrigação aplicada. As lâminas de irrigação aplicadas nos tratamentos T50, T75, T100 e T125 aumentaram em 3,8; 5,3; 12,3 e 10,6\% o 
comprimento das hastes em relação ao tratamento T25. O diâmetro das hastes teve um aumento de $8,0 \%$ no tratamento T125 em relação ao tratamento T25. Para o comprimento e o diâmetro dos botões florais, o tratamento T125 foi o que apresentou melhores resultados, com aumento de 5,8 e 5,95\%, respectivamente, em relação a T25.

$\mathrm{Na}$ análise de massa fresca e massa seca dos botões florais, o aumento nos tratamentos T100 e T125 em relação ao tratamento T25 foi de 11,44 e 12,45\% para massa fresca e 4,24 e 6,1\% para massa seca, respectivamente. De acordo com os valores médios observados no IAF, os tratamentos T50, T75, T100 e T125 apresentaram aumento em relação ao tratamento $\mathrm{T} 25$ de 36,$1 ; 114 ; 191,1$ e 207,4\%, respectivamente.

$\mathrm{Na}$ análise da produtividade de rosas, a aplicação da maior lâmina de irrigação correspondendo ao tratamento T125 obteve o melhor resultado, aumentando a produtividade em $82,5 \%$ em relação ao tratamento T25. Esta produtividade correspondeu a uma diferença de $7.700 \mathrm{dz} /$ ha de rosas entre os dois tratamentos. $\mathrm{O}$ tratamento T125 obteve uma produtividade média de $17.033 \mathrm{dz} /$ ha, enquanto os tratamentos T100, T75, T50 e T25 apresentaram uma produtividade de 15.866; 15.633; 13.300 e $9.333 \mathrm{dz} / \mathrm{ha}$, respectivamente. 


\section{IRRIGATION MANAGEMENT IN ROSE CROP CULTIVATED IN PROTECTED ENVIRONMENT}

\section{SUMMARY}

An experiment was carried out in a commercial rose farm at Atibaia city from $14 / 10 / 99$ to $14 / 12 / 99$, in order to evaluate stems and flower buds quality of rose, cv. "Osiana", and its yield in greenhouse. A small evaporation pan with $0,60 \mathrm{~m}$ of diameter and $0,25 \mathrm{~m}$ of height was installed in the middle of a plastic greenhouse with $39,0 \mathrm{~m}$ of length and $6,5 \mathrm{~m}$ of width. The experimental layout was complete randomized blocks, with five blocks and five treatments. Irrigation water depths were applied at $25,50,75$, 100 and $125 \%$ of evaporation pan at an interval of two days. The parameters evaluated were length and diameter of stems; length, diameter, fresh weight and dry weight of flower buds; leaf area index and yield.

The results showed that there was no significative difference among the treatments for the evaluated parameters, however the stems and buds quality, the LAI and rose yield increased with the irrigation water depth. Irrigation water depths applied on treatments T50, T75, T100 and T125 increased stems length 3.8, 5.3, 12.3 and 10.6\% when compared to T25. Stems diameter for T125 was $8.0 \%$ higher than T25. Treatment T125 showed the best results for buds length and diameter, which were 5.8 and $5.95 \%$ higher than $T 25$, respectively. 
Fresh and dry weight of buds for $\mathrm{T} 100$ and $\mathrm{T} 125$, compared to $\mathrm{T} 25$, increased 11.44 and $12.45 \%$ for fresh weight and 4.24 and $6,1 \%$ for dry weight, respectively. Accordingly to observed LAI average values, the treatments T50, T75, T100 e T125 were $36.1,114,191.1$ e $207.4 \%$ higher than $\mathrm{T} 25$, respectively.

Application of highest irrigation water depth on treatment T125 gave the best results, resulting in rose yield $82.5 \%$ higher than T25. The yield difference between these two treatments corresponded to a difference of $7700 \mathrm{dz} /$ ha. Treatment $\mathrm{T} 125$ showed an average yield of $17033 \mathrm{dz} / \mathrm{ha}$, while T100, T75, T50 and T25 of 15866; $15633 ; 13300$ e $9333 \mathrm{dz} / \mathrm{ha}$, respectively. 


\section{INTRODUÇÃO}

A produção brasileira de flores e plantas ornamentais ocupa uma área de aproximadamente 4.500 hectares distribuídos nos estados de São Paulo, Rio de Janeiro, Minas Gerais, Santa Catarina e Rio Grande do Sul. O mercado brasileiro de flores e plantas ornamentais movimenta em torno de R\$ 1 bilhão ao ano e possui uma taxa de crescimento em torno de $20 \%$ ao ano, podendo ser considerada uma das maiores taxas de crescimento de toda a economia brasileira (Arruda, 1996).

Em relação ao comércio de flores cortadas, em 1994 a cultura da rosa respondeu por aproximadamente 10 milhões de dúzias produzidas em dois municípios do estado de São Paulo, Holambra e Atibaia. A sua exportação respondeu por aproximadamente US\$ 2 milhões, fícando em segundo lugar, perdendo apenas para as mudas de plantas ornamentais (IBRAFLOR, 1997).

O Brasil possui grande potencial para tornar-se um grande produtor e exportador de flores e plantas ornamentais, destacando-se a cultura de rosas que já ocupa um lugar de destaque na floricultura brasileira.

O mercado consumidor e principalmente o mercado externo exigem quantidade e qualidade das rosas produzidas. Para isto, faz-se necessário um conhecimento completo sobre a cultura da rosa. Embora haja difusão de tecnologia importada para os floricultores por parte de algumas empresas privadas, existem poucos dados científicos de produção e exigência da planta no Brasil. 
Muitas pesquisas sobre a necessidade de água têm sido realizadas para as grandes culturas, determinando-se através de lisímetros ou estimando-se através de dados meteorológicos e fórmulas empíricas o consumo de água, entretanto para as culturas cultivadas sob ambiente protegido a pesquisa está defasada em relação a outros países, principalmente na floricultura.

A utilização de ambientes protegidos para a produção de rosas é recente no Brasil, sendo utilizado manejos de controle do microclima e tecnologia de irrigação de outros países. A grande maioria das informações são originárias de outros países, como Israel, França, Estados Unidos e Colômbia, onde as condições climáticas são diferentes do Brasil.

O correto manejo da irrigação permite aplicar a água em quantidades adequadas promovendo o uso mais eficiente dos fertilizantes e da energia utilizada no sistema de irrigação, criando condições para produção de rosas de melhor qualidade.

O objetivo do presente trabalho foi avaliar a qualidade e a produtividade da cultura de rosa, produzida em ambiente protegido, através de diferentes lâminas de irrigação determinada com o auxílio de um tanque evaporimétrico reduzido. 


\section{REVISÃ DE LITERATURA}

\subsection{A cultura da rosa}

\subsubsection{Origem}

O gênero $\underline{\text { Rosa }}$ sp teve origem na Ásia, onde foi agrupado em dois grandes grupos, as Rosas da China e as Rosas da Pérsia e Ásia Menor. A distribuição da rosa no mundo ocorreu da Ásia para a Europa e América. A grande aceitação e comercialização das rosas geraram vários cruzamentos artificiais, obtendo-se as variedades atuais de alto valor comercial (Urcullu, 1953).

No mundo, estima-se que haja em torno de 30 mil variedades de rosas, produzidas através de cruzamentos artificiais. Os países que mais investem em pesquisas para obtenção de novas variedades são: Holanda, Alemanha, Estados Unidos e Colômbia, sendo estas pesquisas patrocinadas geralmente por empresas privadas. Atualmente, as variedades de rosas são distinguidas principalmente pela coloração das pétalas, forma do botão, tamanho das hastes, produtividade (hastes. $\mathrm{m}^{-2}$ ) e resistência às doenças.

Morfologicamente, as roseiras cultivadas atualmente diferem das roseiras silvestres (Bañon Arias et al., 1993). Taxonomicamente, a rosa pertence a Classe das Angiospermas, Subclasse Dicotiledônea, Ordem Rosales e Família Rosaceae. Apresenta grande facilidade de cruzamentos possibilitando gerar híbridos. 


\subsubsection{Importância econômica}

A produção de rosas ocorre em vários municípios do Estado de São Paulo, entre eles Atibaia, Bragança Paulista, Piracaia e Holambra como os maiores produtores.

Segundo pesquisa realizada pelo CEAGESP-SP em 1991, Atibaia respondia por $64 \%$ da produção de rosas comercialiazada pelo CEAGESPSP, seguido por Bragança Paulista com $11 \%$ e Piracaia com $9 \%$.

O município de Holambra também se destaca por ser um grande produtor de rosas, sendo comercializada no próprio município através de leilão e através dos CEASA de São Paulo e Campinas. Outra região produtora de rosas é o Sul do estado de Minas Gerais tendo em vista o clima propício para a produção.

Em relação ao comércio de flores cortadas, em 1994 a cultura da rosa respondeu por aproximadamente 10 milhões de dúzias produzidas nos municípios de Atibaia e Holambra. A exportação de rosas respondeu por aproximadamente US\$2 milhões ficando em segundo lugar, perdendo apenas para as mudas de plantas ornamentais (IBRAFLOR, 1997).

Com a abertura do setor de floricultura ao mercado externo, as rosas de outros países da América do Sul como Colômbia e Equador tem competido com as rosas produzidas no Brasil, mas ainda em pequena quantidade devido ao custo do transporte e baixa infra-estrutura por parte dos importadores. Em virtude da concorrência externa, produtores brasileiros que antes não se preocupavam com a qualidade da produção, agora tem adotado técnicas que visam o aumento de produtividade $\mathrm{e}$ qualidade, além de padronização da produção e uso de embalagens adequadas. Estas técnicas incluem o plantio de rosas em ambiente protegido, implantação de sistema de fertirrigação e controle da temperatura e umidade relativa do ar. Entretanto, a competição com a rosa importada é real, dado a alta aceitação pelos floristas brasileiros, pois as rosas são de alta qualidade em função da alta qualidade. 
A rosa é comercializada o ano inteiro nos entrepostos e em leilões, no entanto a comercialização é mais intensa em datas especiais, como dia das mães, dia dos namorados, dia da secretária e festas de fim de ano.

A produção de flores e plantas ornamentais, no estado de São Paulo permite a criação de mais de 28,5 mil empregos, dos quais, $45 \%$ na produção de flores, $7 \%$ na distribuição, $44 \%$ no comércio e $4 \%$ na indústria de apoio. Na produção de flores e plantas ornamentais a área média dos produtores está em torno de 3 ha, empregando de 4 à 10 pessoas por hectare, dos quais $86 \%$ são mensalistas e $4 \%$ diaristas eventuais (Kämpf, 1997).

O número de cultivares plantados é muito grande devido ao número de híbridos lançados no mercado todos os anos. Há várias empresas especializadas em propagação de rosas, como por exemplo, a Meilland, Kordes e Preesman onde o objetivo principal é satisfazer o mercado consumidor com rosas produtivas, durabilidade pós-colheita, resistência a pragas e doenças, compatibilidade aos porta-enxertos, diâmetro e resistência do caule, folhagem abundante, fácil propagação, flores com tamanho, aroma e forma aceitáveis no mercado (Bañon Arias et al., 1993).

\subsubsection{Características da planta}

A roseira é uma planta arbustiva, perene com hábito de crescimento ereto, caule lenhoso e normalmente espinhoso. As folhas são pinadas, caducas e compostas de cinco a sete folíolos ovalados. Emite ramos basais na primavera e em condições de casa de vegetação onde, a temperatura é mais alta. Os ramos basais são galhos mais grossos que permitirá a planta formar o seu esqueleto e produzir hastes florais para comercialização. As flores se desenvolvem no ápice das hastes contendo 
normalmente cinco sépalas com lóbulos laterais e fruto do tipo carnoso (Bañon Arias et al., 1993).

\subsubsection{Efeito da temperatura e umidade relativa do ar e radiação solar na cultura da roseira.}

A faixa ótima de temperatura para o crescimento da roseira está entre $17^{\circ} \mathrm{C}$ e $26^{\circ} \mathrm{C}$. Temperatura acima de $25^{\circ} \mathrm{C}$ acelera o florescimento deixando as flores pequenas e coloração pálida, enquanto, temperaturas baixas pode atrasar seu crescimento e floração (Salinger, 1991).

Moe (1988), estudou o florescimento e qualidade de hastes de rosas de 3 cultivares (Sonia, Belinda e Red Gernette) cultivadas em temperaturas diferentes, constante a $12^{\circ} \mathrm{C}$, constante à $18^{\circ} \mathrm{C}$ e variável com média de $18^{\circ} \mathrm{C}$. Observou que a produção de hastes de rosas cultivadas a temperatura constante de $18^{\circ} \mathrm{C}$ tiveram o tempo de colheita diminuida em $50 \%$ para as 3 cultivares. A produtividade foi $2,5-3,0$ vezes maior do que em temperatura constante a $12^{\circ} \mathrm{C}$ para as cultivares Belinda e Red Garnette. Na temperatura constante de $18^{\circ} \mathrm{C}$, a cultivar Sonia teve 5 picos de produção em 8 meses, enquanto que, na temperatura constante de $12^{\circ} \mathrm{C}$ houve apenas 2 picos de produção. Em relação a qualidade das hastes de rosas, observou que em temperatura acima de $21^{\circ} \mathrm{C}$ as hastes se tornaram curtas, frágeis, com internódios curtos e botões pequenos com coloração pálida. Em temperatura abaixo de $15^{\circ} \mathrm{C}$ observou que as hastes tinham flores mal formadas e hastes cegas, ou seja, sem formação do botão floral.

Bañon Arias et al. (1993), também descreve que a fase crítica para a cultura da roseira é o início do desenvolvimento dos brotos, onde baixas temperaturas podem originar hastes cegas e botões deformados.

Em relação a radiação solar, Mastalerz (1987) descreve que para a produção de rosas em ambiente protegido a luz é um fator dominante. 
Quanto maior a disponibilidade de luz, maior a fotossíntese, mas quando a absorção das folhas atingir o máximo não haverá mais incremento na fotossintese, permanecendo estável. A capacidade da planta em interceptar e usar a energia luminosa para fazer fotossintese determina a disponibilidade de carboidratos para seu crescimento. Com isto, quanto maior a área foliar, maior será a fotossintese, elevando a produtividade e a qualidade das hastes de rosas.

O autor descreve ainda que a alta umidade do solo e o nível adequado da adubação contribuem para um rápido crescimento e um bom tamanho das folhas para a realização da fotossíntese e o estresse hídrico juntamente com uma frequência de irrigação inadequada restringe essa expansão foliar diminuindo a fotossíntese.

Baille et al. (1994) estudaram o efeito da radiação solar sobre a transpiração na cultura da rosa e mostraram que sob uma radiação moderada a transpiração foi aproximadamente proporcional a radiação solar e sob alta taxa de radiação solar não houve relação linear com a transpiração.

Com o intuito de medir a quantidade de hastes de rosas em relação a radiação solar, Moreshet et al. (1976) contaram a produção de flores em canteiros dispostos no sentido leste-oeste e observaram que a produção foi maior na parte do canteiro disposto a leste. Em relação a transmissividade da radiação solar na estufa, não houve diferença entre o leste e o oeste. A menor produção de hastes na parte oeste foi explicada pela menor atividade fotossintética das folhas durante a tarde devido ao fechamento dos estômatos. Outro fato, foi que havia maior concentração de $\mathrm{CO}_{2}$ durante à noite, onde as plantas da parte leste aproveitavam melhor a concentração de $\mathrm{CO}_{2}$ acumulado logo após o surgimento do sol.

A produtividade da roseira está relacionado com a intensidade de energia solar ao longo do ano (Post \& Howland, 1946). No inverno a produção de flores é menor quando comparado com o verão, devido à 
menor taxa de luz incidente e menor fotoperíodo. Em relação à qualidade das flores, como, tamanho e diâmetro das hastes, comprimento do botão, diâmetro do botão e número de pétalas, no verão esses parâmetros são menores em relação ao inverno devido ao aumento substancial na temperatura no interior da estufa ultrapassando a temperatura ótima para a cultura. Outra mudança que ocorre no verão é o tempo de produção das hastes florais, diminuindo de 8 semanas no inverno para 5 semanas no verão (Mastalerz, 1987).

Em relação a umidade relativa do ar, Pereira et al. (1997) descreve que o ar envolve uma quantidade muito grande de vapor de água que se satura em algumas ocasiões especiais, quando isso não ocorre, a pressão parcial de vapor $\left(e_{a}\right)$ é menor que a pressão de saturação $\left(e_{s}\right)$, ocorrendo um déficit de saturação representado pela diferença $\left(\mathrm{e}_{\mathrm{s}}-\mathrm{e}_{\mathrm{a}}\right)$. Quando a temperatura do ar aumenta, a pressão de saturação (es) também aumenta, resultando em maior déficit e consequentemente maior capacidade do ar em reter vapor de água. A umidade relativa pode ser calculada pela equação:

$$
U R \%=\frac{e_{a}}{e_{s}} \times 100
$$

onde,

$$
\begin{aligned}
& \text { UR\% - umidade relativa do ar (\%) } \\
& e_{a} \text { - pressão parcial de vapor, } \\
& \mathbf{e}_{s} \text { - pressão de saturação }
\end{aligned}
$$

A umidade relativa do ar influi na transpiração das plantas uma vez que pelos estômatos fluem gás carbônico, oxigênio e vapor de água. Quando a demanda atmosférica é elevada as plantas não conseguem repor a água através das raízes, fechando seus estômatos para não perder água para o ambiente. Quando o ar tem umidade relativa suficiente, a planta 
mantém seus estômatos abertos permitindo trocas entre as folhas e o ambiente.

Segundo Bañon Arias et al. (1993), a umidade relativa do ar ideal para a cultura da roseira está entre $70-75 \%$, sendo que para o período de brotação das gemas e crescimento dos brotos é aconselhável uma umidade relativa do ar entre 80 - 90\%. A permanência de umidade relativa alta na estufa pode provocar doenças como Botrytis e a umidade relativa baixa $(>60 \%)$ pode provocar distúrbios físiológicos.

Gislerod et al. (1987) estudando 9 espécies de plantas incluindo rosa em estufa, observaram que houve uma diminuição de 44 à $60 \%$ na taxa de transpiração devido ao aumento da umidade relativa do ar de 55 para $95 \%$.

\subsection{Efeito do ambiente protegido na temperatura e na umidade relativa do ar.}

O uso de ambiente protegido tem inúmeras vantagens frente as adversidades climáticas predominantes em algumas regiões, onde o clima limita o cultivo a céu aberto.

Do ponto de vista térmico, os ambientes protegidos apresentam às vezes comportamento contrário, pois de dia atinge temperaturas elevadas e a noite atinge temperaturas críticas para a produção (Martinez Garcia, 1986).

Segundo Prados (1986) e Martinez Garcia (1978) a cobertura plástica interfere no balanço de energia no interior do ambiente protegido, que por sua vez é função de fatores como as condições da cobertura, ângulo de incidência da radiação solar sobre a cobertura, tipo de solo, tamanho da estufa e volume da estufa. Todos estes fatores influem no chamado "efeito estufa" onde a radiação solar que penetra na estufa é convertida em energia térmica (comprimento de onda longa) pela absorção parcial do solo e das plantas. A irradiação dessa energia térmica 
(onda longa) para o espaço atinge a cobertura plástica e fíca retida no ambiente aumentando a temperatura do ar em seu interior. Mas nem sempre a cobertura plástica retém toda a irradiação da onda longa, deixando passar parte dessa energia para fora da estufa. Segundo Tapia (1981), o polietileno de baixa densidade (PEBD), o mais usado no Brasil para cobertura de estufas, deixa passar de 70 a $90 \%$ da radiação de onda curta para dentro da estufa, mas permite passar $80 \%$ da radiação de onda longa para fora da estufa. Devido a isto, pode ocorrer com certa frequência temperaturas inferiores às críticas das plantas cùltivadas, fenômeno esse conhecido por "Inversão Térmica" (Buriol et al., 1993; Camacho et al., 1995).

A umidade relativa do ar varia muito no interior de um ambiente protegido e está intimamente relacionado aos valores de temperatura do ar. Para uma mesma quantidade de vapor de água no ar, a umidade relativa é inversamente proporcional à temperatura (Prados, 1986). Com isto, durante o dia, com o aumento da temperatura, a umidade relativa do ar diminui. Porém, durante à noite, a umidade relativa aumenta sensivelmente chegando a $100 \%$ antes do nascer do sol, devido a queda na temperatura e na retenção do vapor de água pela cobertura (Tanaka \& Genta, 1982; Prados, 1986). A quantidade de vapor de água no interior de um ambiente protegido é influenciado pela evapotranspiração da cultura associado com a baixa permeabilidade da cobertura plástica ao vapor de água e a baixa renovação do ar no seu interior provocando um acúmulo deste vapor de água no ambiente (Robledo \& Martin, 1981; Bailey, 1985).

$\mathrm{Na}$ cultura da rosa, a temperatura amena associada com o acúmulo de vapor de água no interior da estufa faz com que haja condensação deste vapor de água no teto da estufa, com isso as gotas caem sobre as folhas tornando o ambiente favorável para a germinação dos esporos de fungos (Hand, 1988). 


\subsection{Evapotranspiração}

A palavra evapotranspiração foi usada por Thornthwaite para expressar a evaporação da água pelo solo e a água utilizada pela planta em seu processo metabólico chamado transpiração.

A quantidade de água evapotranspirada depende primeiramente da planta, do solo e do clima, sendo este último, o fator mais importante para a estimativa da evapotranspiração.

A estimativa da evapotranspiração de uma cultura pode ser feita pelos métodos diretos e indiretos. O método direto é realizado através de lisímetros de pesagem onde permite determinar da evapotranspiração de uma cultura em períodos curtos e o método indireto é realizado através de modelos matemáticos baseados em dados climáticos. Nos anos 70 , os modelos para calcular a evapotranspiração de uma cultura eram apenas baseados na radiação solar global e em vários coeficientes como o coeficiente da cultura $(\mathrm{Kc})$ :

$$
E T=K c \times(a+b \times R G)
$$

onde,

$$
\begin{aligned}
& \text { Kc - coeficiente da cultura } \\
& \text { RG - radiação solar global } \\
& \text { a, b - coeficientes matemáticos }
\end{aligned}
$$

Recentemente, foram desenvolvidos modelos para estimar a evapotranspiração baseados em fatores climáticos como a radiação solar global, o déficit de pressão de vapor e parâmetros específicos da cultura como a resistência estomática e o índice de área foliar. Esses modelos de equações, como proposto por Monteith (1965) são mais elaborados e 
fornecem dados mais precisos da necessidade de água pela cultura e também condições para um manejo eficiente do ambiente (Baille, 1992).

Segundo Boulard \& Jemaa (1993), a transpiração de uma cultura em estufa é guiado pelo déficit de saturação de vapor de água entre o ar e as folhas. Para medir a saturação é necessário conhecer os valores de temperatura das folhas, o que torna o modelo para estimar a evapotranspiração muito difícil. Com isso, adotaram uma combinação que permite estimar a transpiração através de leituras de parâmetros climáticos como a radiação absorvida pela cultura e o déficit de pressão de vapor.

Baille et al. (1993) estudando a transpiração da cultura de rosa em estufa compararam a transpiração com o déficit de pressão de vapor em ambiente com nebulização e sem nebulização. Observaram que os valores máximos de déficit de pressão de vapor no sistema com nebulização não excederam $1,5 \mathrm{kPa}$ e a transpiração aumentou quase linearmente com o déficit de pressão de vapor enquanto que no sistema sem nebulização o valor do déficit de pressão de vapor alcançou $3,0 \mathrm{kPa}$ e a transpiração mostrou uma significante diminuição devido ao fechamento do estômatos.

Bozarth et al. (1992), Pasian \& Lieth (1989) observaram que a resistência dos estômatos é influenciada em grande parte pela radiação solar global e pelo déficit de pressão de vapor. Observaram também que a influência da temperatura do ar sobre a resistência é muito pequena.

Baille \& Baille (1992) observaram que a taxa de transpiração comparado com a radiação solar incidente sobre a cultura da rosa é baixa. A causa disto pode ser atribuída a cultura em pé franco não ter um índice de área foliar adequado e a taxa de déficit de pressão de vapor de água ser crítico para a resistência dos estômatos. Concluíram também que a estimativa da evapotranspiração pela fórmula de Penman-Monteith usando as fórmulas de radiação solar e déficit de pressão de vapor foi capaz de simular os valores de evapotranspiração com segurança. 
Baille et al. (1992) estudando a resistência estomática compararam dois métodos. Um método usando a fórmula de PenmanMonteith para estimar a evapotranspiração com radiação liquida, tensão de vapor, temperatura interna do ar e índice de área foliar. No outro método, adicionou-se a esses parâmetros a temperatura da parte aérea da planta. O método usando a fórmula de Penman-Monteith apresentou maior segurança e correlações elevadas. Já o outro método não teve boa correlação, pois a medição da temperatura da parte aérea da planta foi de difícil determinação.

Outros métodos para estimar a evapotranspiração foram propostos, como por exemplo o de Bakker (1986), em que se baseava no balanço de água dentro da estufa utilizando a taxa de troca de ar dentro da estufa e da diferença entre as umidade específicas dentro e fora. A dificuldade em obter dados seguros dessas taxas de troca de ar foi elevada, dificultando o seu emprego.

\subsection{Importância da água para a cultura da rosa}

Os sintomas de estresse hídrico que a roseira apresenta depende da sua intensidade e da sua frequência. A ocorrência de estresses repetidos pode causar encurvamento e secamento das bordas das folhas e senescência da mesma. A ocorrência de estresse hídrico por um longo período torna a planta mais lenhosa, anã, com folhas pequenas, com coloração mais clara, sem brilho e com desproporção entre o tamanho do botão e o tamanho das folhas da haste comercial (White \& Holcomb, 1987).

Segundo Caballero et al. (1996) o estresse hídrico não deve ocorrer durante a formação das folhas da haste comercial, onde apesar de não afetar a qualidade das hastes, há um atraso de 10 a 15 dias na produção. A fase em que a roseira não deve sofrer estresse hídrico é 
quando a haste e o botão estão com a maior taxa de crescimento, isso ocorre durante o final da elongação da haste e formação do botão floral, antes de sua abertura.

Não é somente a falta de água que causa injúrias na roseira, o excesso de umidade no solo diminui sensivelmente a aeração do solo causando um crescimento anormal da planta. Os sintomas incluem amarelecimento, clorose internerval e perdas das folhas. Nas raízes, geralmente ocorre um escurecimento em toda sua extensão.

Shanks \& Laurie (1949) descreveram a aparência das raízes da roseira em 4 condições de umidade. a) Solo muito úmido: as raízes velhas são espessas, macias, esponjosas e possuem uma casca de coloração marrom claro e são quebradiças. As raizes jovens têm muitas ramificações brancas com oito a dez centímetros de comprimento e poucas ou nenhuma radicelas. b) Solo mediamente úmido: as raízes velhas apresentam coloração marrom claro e muito ramificada, enquanto as raízes novas são compridas e esbranquiçadas. c) Solo seco: as raízes velhas são longas, finas e coloração marrom escura. As raízes novas são curtas, quebradiças, com coloração marrom claro e pouco desenvolvidas. Em solo seco, somente há abundância de radicelas e ramificações na região das raízes novas. d) Plantas desenvolvidas na água: as raízes velhas são iguais às raízes desenvolvidas em solo muito úmido e as novas possuem ramificações espaçadas e coloração branca.

A determinação da taxa da evapotranspiração depende da cultura, do solo e de fatores atmosféricos. A taxa de evaporação depende da altura da planta. Canteiros com plantas novas tende a evaporar mais água da superfície do solo do que canteiros com plantas adultas, pois estas fazem mais sombra diminuindo a taxa de evaporação. A taxa de transpiração depende da planta e de fatores atmosféricos como, a radiação no interior da estufa, a umidade relativa, os ventos $e$ a temperatura do ar no interior da estufa. Na roseira, a necessidade de água 
depende primeiramente da taxa de transpiração, que geralmente fica em torno de 500 e 1000 gramas de água para cada grama de seu peso seco em todo o ciclo (White \& Holcomb, 1987).

Caballero et al. (1996) mediu o consumo de água pela roseira cultivada em substrato e observou que no verão a taxa era de 2,5 à 3,6 $\mathrm{mm}$ e no inverno era de 1,0 à $2,5 \mathrm{~mm}$, mas em dias muito quentes e secos as folhas novas apresentavam sintomas de estresse hídrico resultando em flores impróprias para a comercialização.

Plaut \& Zieslin (1977) estudando o efeito do molhamento da parte aérea da roseira observaram que houve uma diminuição no número de flores colhidas e um aumento na média do peso dos botões florais, concluindo que o efeito direto do molhamento da parte aérea foi uma redução na taxa de transpiração.

Agbaria et al. (1995) estudando a taxa de transpiração em roseira enxertada e não enxertada verificou que houve uma redução pronunciada no comportamento dos estômatos acompanhado de uma diminuição de $65 \%$ na taxa de transpiração da rosa enxertada em relação a rosa não enxertada.

\subsection{Manejo da irrigação}

As questões relacionadas a quando e quanto irrigar são importantes para os agricultores, pois devido aos aumentos do custo de energia e da escassez do recurso água o produtor passa a ter posturas diferenciadas a cerca do assunto, tornando o manejo racional da irrigação um processo indispensável no processo produtivo das culturas irrigadas (Hernandez, 1997). A avaliação do consumo de água de uma cultura é de fundamental importância do ponto de vista agrícola, principalmente 
considerando-se que os recursos hídricos disponíveis são limitados, principalmente nas zonas áridas e semi-áridas (Alves, 1996).

O clima é um dos principais fatores na determinação do volume de água evapotranspirado pelas culturas. Além dos fatores climáticos, a evapotranspiração também é influenciada pela própria cultura. $O$ meio ambiente e o manejo agronômico também podem influir na taxa de crescimento e na evapotranspiração (Doorenbos \& Pruitt, 1997).

Os métodos de manejo da irrigação podem se agrupar em três categorias, nos parâmetros climáticos, nas medidas de umidade $\mathrm{e}$ potencial da água no solo e nas medidas do potencial da água nas plantas. Existe ainda o método conjugado baseando-se nos parâmetros climáticos e nas condições do solo (Pizarro, 1996; Hernandez, 1997).

Dentre os vários métodos indiretos utilizados para estimativa da evapotranspiração, o método do tanque Classe A é um dos mais utilizados, pois mede o efeito integrado da radiação solar, vento, temperatura e umidade relativa sobre a evaporação de uma superfície livre de água, onde a planta responde as mesmas variáveis climáticas, estimando assim, a evapotranspiração de referência (Eto). (Doorenbos \& Pruitt, 1997; Klar, 1991).

Existem vários tipos de tanques de evaporação, sendo o tanque USWB Classe A o mais usado devido a maior precisão, praticidade e economia (Withers \& Vipond, 1974; Klar, 1991). Esse tanque consiste de um recipiente circular, construído, normalmente, de aço galvanizado com $1,21 \mathrm{~m}$ de diâmetro interno e $0,25 \mathrm{~m}$ de altura e cheio de água até que o seu nível fique a $0,05 \mathrm{~m}$ da borda superior do tanque. A evaporação é medida através de um micrômetro de gancho, assentado sobre um poço tranquilizador (Stone \& Silveira, 1995).

Martinelli \& Villa Nova, (1989), comparando os resultados de evapotranspiração de referência através dos métodos mais utilizados, tanque classe A, método da radiação solar, Thornthwaite, Thornthwaite 
modificado, Penman, Penman modificado e Linacre verificou que o método do tanque Classe $\mathrm{A}$ obteve dados mais próximos da realidade, pois a evaporação obtida é resultante da ação de diversos elementos climáticos.

Medeiros et al. (1997), cita que atualmente, o tanque "Classe A" tem sido utilizado para manejo da irrigação no interior de ambientes protegidos, mas por ocupar grande espaço no interior da estufa tem-se adotado tanques de dimensões reduzidas para estimar a evapotranspiração. Com isto, foi realizado um experimento comparando o tanque classe A padrão com um tanque reduzido com dimensões menores, apresentando $0,6 \mathrm{~m}$ de diâmetro e $0,35 \mathrm{~m}$ de altura instalado no interior de uma estufa. $O$ resultados mostraram uma correlação igual a 0,96 entre os dois tanques instalados na estufa.

Farias et al. (1994) quantificou a evaporação em um tanque "Classe A" e em um tanque reduzido com dimensões de $0,2 \mathrm{~m}$ de diâmetro e $0,25 \mathrm{~m}$ de altura instalado no centro de uma estufa plástica utilizando dados de coeficiente de tanque (Kp) igual a 1,0 para o interior de estufas plásticas e os coeficientes apresentados por Doorenbos e Pruitt, verificaram que a evaporação no tanque reduzido foi menor que a evaporação no tanque classe A. Comparando os valores dos dois evaporímetros no interior da estufa observaram que a correlação entre elas foi bem elevada $\left(\mathrm{r}^{2}=0,79\right.$ a 0,81$)$, indicando a possibilidade do uso do tanque reduzido, no interior da estufa, para estimar a evapotranspiração de referência, ao invés do tanque classe $A$, sendo mais aconselhável por ocupar menor área e menor custo, além de haver maior praticidade.

\subsubsection{Coeficiente de cultivo}

Para medir os efeitos das características da cultura sobre as necessidades hídricas das plantas, utilizam-se coeficientes de cultivo 
(Kc) que relacionam a ETo com a evapotranspiração da cultura (ETc). O valor de Kc representa a evapotranspiração de uma cultura em condições ótimas que proporcionam ótimos rendimentos (Doorenbos e Pruitt, 1997).

Ainda Doorenbos e Pruitt, (1997) citam que para a escolha dos valores de Kc são consideradas, as características da cultura, momento do plantio ou semeadura e as fases do desenvolvimento vegetativo. Além desses fatores, considera-se ainda a condição climática e em especial, o vento e a umidade relativa do ar, pois após os valores de temperatura, o vento é quem mais influencia a taxa de evapotranspiração, devido ao grau de turbulência do ar sobre a superfície sombreada pela cultura.

Segundo Wrigth (1982), quando as irrigações são diárias ou freqüentes, como ocorre em ambiente protegido com sistema de irrigação por gotejamento colocados na superficie do solo, é necessário estimar a ETc diariamente. Isto implica que os valores de Kc devem ser obtidos utilizando-se do conceito de coeficientes basais ou de base $(\mathrm{Kcb})$, pois incorpora o ajuste devido ao molhamento da superfície do solo na época de irrigação ou chuva e o efeito do déficit hídrico.

$$
K c=k s \times k c b+k e
$$

onde,

$\mathrm{Kcb}$ : corresponde à relação entre Etc e Eto quando a camada superficial do solo está seca, mas a zona radicular está adequada para manter a cultura com transpiração plena (varia de 0 à 1,4 ).

Ks: coeficiente de déficit hídrico do solo $(\mathrm{Ks}=1,0)$.

Ke: coeficiente de evaporação solo (varia de 0 à 1,4 ). 


\section{MATERIAL E MÉTODOS}

A roseira (Rosa sp.) utilizada neste experimento apresentava aproximadamente 4 anos de idade, cultivada em estufa com espaçamento de $0,20 \mathrm{~m}$ entre plantas e $0,30 \mathrm{~m}$ entre linhas, sendo duas linhas de plantio por canteiro. A cultivar utilizada foi a Osiana, possuindo coloração das pétalas a rosa-creme (champagne). Esta cultivar apresenta alta produtividade, hastes retas com comprimento acima de $60 \mathrm{~cm} \mathrm{e}$ diâmetro do caule entre 0,60 e 0,90 cm (Figura 1).

O experimento foi conduzido na propriedade rural onde a única prática alterada foi em relação às lâminas de irrigação aplicadas, os tratos fitossanitários e a condução da cultura da roseira (podas e desbrotas) seguiram o programa desenvolvido pelo produtor.

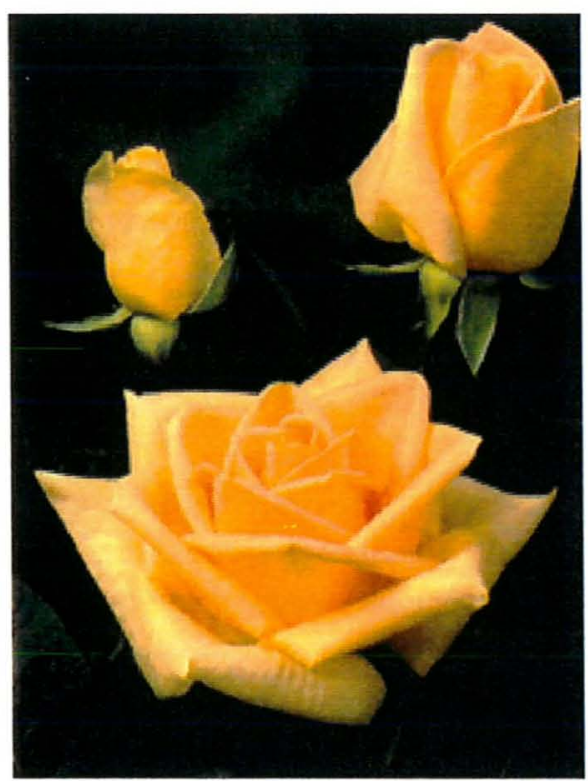

Figura 1. Cultivar Osiana (Champgne) utilizada no experimento. 


\subsection{Localização geográfica}

O experimento foi instalado no sítio de produção comercial de rosas Shimokuma Flores, situado no municipio de Atibaia, região de Bragança Paulista, distante $65 \mathrm{Km}$ de São Paulo, cujas coordenadas geográficas são Latitude de $23^{\circ} 08^{\prime} \mathrm{S}$, longitude de $46^{\circ} 33^{\prime} \mathrm{W}$ e $805 \mathrm{~m}$ de altitude. As condições climáticas do município apresentam temperatura média de $19,9^{\circ} \mathrm{C}$, temperatura máxima média de $26,1^{\circ} \mathrm{C}$ e temperatura mínima média de $13,6^{\circ} \mathrm{C}$, ideais para produção de rosas.

O ensaio foi instalado na terceira estufa de um bloco de cinco estufas germinadas dispostas no sentido Norte-Sul. O bloco de estufas ocupava uma área de $1250 \mathrm{~m}^{2}$, sendo cada estufa com $250 \mathrm{~m}^{2}$, pé direito com $3,30 \mathrm{~m}$ de altura e cobertura plástica de polietileno transparente com espessura de 100 micra suportada por arco de ferro galvanizado. A estufa não apresentava cortina lateral para manejo de temperatura e umidade relativa do ar no interior.

Foi realizada análise granulométrica do solo para as profundidades de $0-0,2 ; 0,2-0,4$ e $0,4-0,6 \mathrm{~m}$, coletadas ao acaso para conhecimento da textura. Os resultados da análise são apresentados na Tabela 1, onde permite concluir que trata-se de um solo de classe média nas camadas mais superficiais e classe argilosa na camada mais profunda.

Tabela 1. Análise granulométrica do solo na área experimental.

\begin{tabular}{cccc}
\hline Profundidade $(\mathrm{cm})$ & \% Argila & \% Silte & \% Areia \\
\hline $\mathbf{0}-\mathbf{2 0}$ & $32, \mathbf{8 8}$ & 19,45 & 47,67 \\
$\mathbf{2 0}-\mathbf{4 0}$ & 37,75 & 17,49 & 44,76 \\
$\mathbf{4 0}-\mathbf{6 0}$ & 44,58 & $\mathbf{1 6 , 2 8}$ & 39,14 \\
\hline
\end{tabular}




\subsection{Determinação da curva característica de água no solo}

Para determinação da curva de retenção na área experimental, foram coletadas nove amostras indeformadas em 3 três pontos da estufa plástica e nas profundidades de 0,20;0,40 e 0,60 m com o auxílio de trado. As amostras foram levadas para o laboratório de física do solo do Departamento de Engenharia Rural da ESALQ/USP para confecção da curva de retenção de água no solo, onde a umidade foi determinada em base volumétrica e ajustada pelo modelo de van Genuchten (1980) para os parâmetros de umidade e tensão (Figura 2.). Os valores dos parâmetros do modelo $\theta \mathrm{r}, \theta \mathrm{s}, \alpha, \mathrm{n}$ e m são apresentados na Tabela 2 .

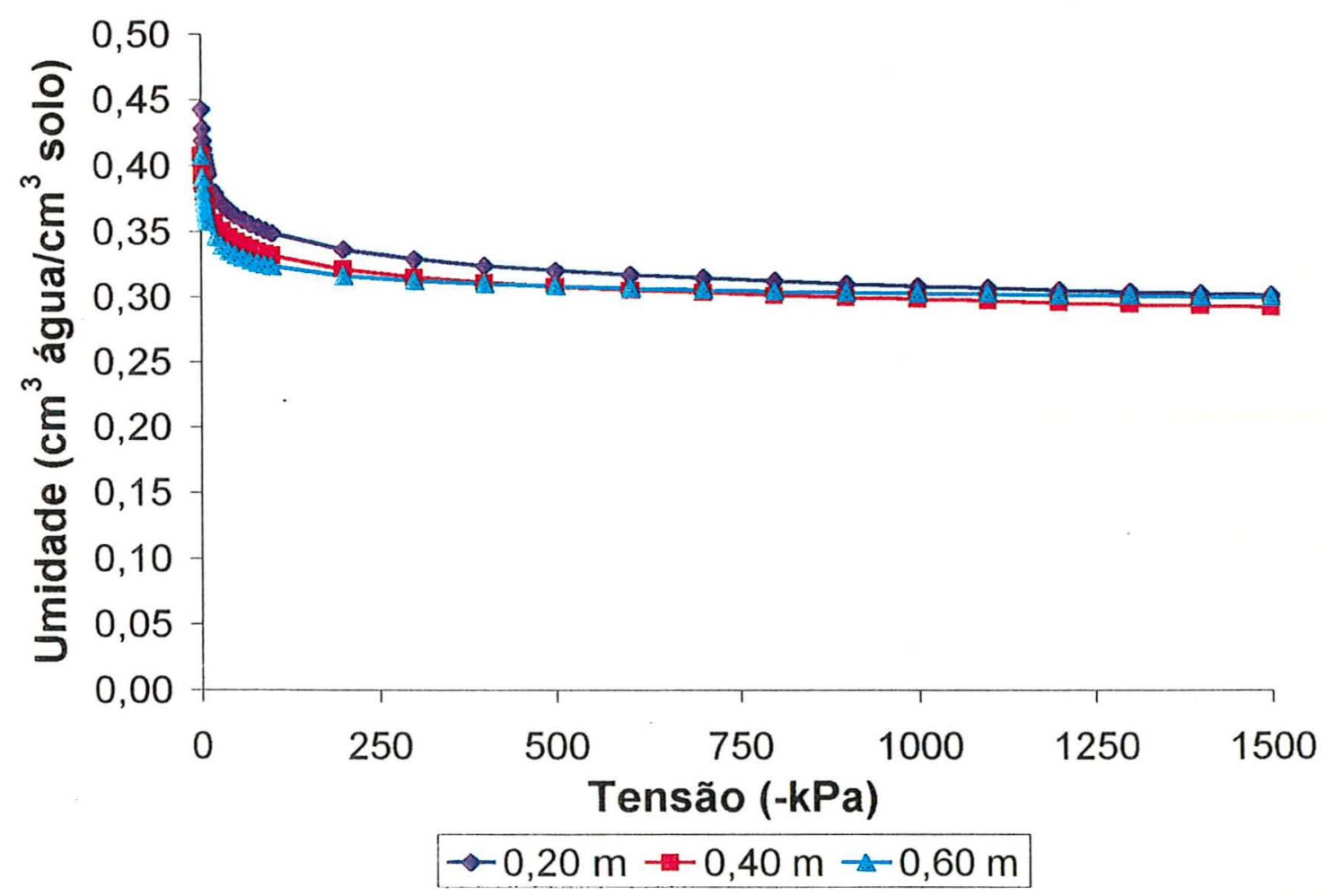

Figura 2. Curva característica de retenção da água no solo para as profundidades de 0,$20 ; 0,40$ e $0,60 \mathrm{~m}$. 
Tabela 2. Parâmetros do modelo de van Genuchten para as profundidades de 0,$20 ; 0,40$ e $0,60 \mathrm{~m}$.

\begin{tabular}{ccccccc}
\hline Profundidade & $\boldsymbol{\theta} \mathbf{r}$ & $\boldsymbol{\theta} \mathbf{s}$ & $\boldsymbol{\alpha}$ & $\mathbf{n}$ & $\mathbf{m}$ & $\mathbf{R}^{2}$ \\
\hline $\mathbf{0 , 2 0} \mathbf{m}$ & 0,0004 & 0,5068 & 11,9252 & 1,0526 & 0,04997 & 0,9828 \\
$\mathbf{0 , 4 0} \mathbf{m}$ & 0,0007 & 0,4578 & 12,1221 & 1,0453 & 0,04334 & 0,9918 \\
$\mathbf{0 , 6 0} \mathbf{~ m}$ & 0,2759 & 0,4477 & 2,4588 & 1,2320 & 0,1883 & 0,9937 \\
\hline
\end{tabular}

Os valores de umidade na capacidade de campo $(30,0 \mathrm{kPa})$ e na tensão máxima suportada pelos tensiômetros $(80,0 \mathrm{kPa})$ para as profundidades de 0,$20 ; 0,40$ e $0,60 \mathrm{~m}$ são apresentados na Tabela 2 .

Tabela 3. Valores de umidade volumétrica do solo nas tensões de $30,0 \mathrm{kPa}$ e $80,0 \mathrm{kPa}$.

\begin{tabular}{lccc}
\hline \multicolumn{1}{c}{ Tensão } & \multicolumn{3}{c}{ Profundidade (m) } \\
\hline & $\mathbf{0 , 2 0}$ & $\mathbf{0 , 4 0}$ & $\mathbf{0 , 6 0}$ \\
& \multicolumn{3}{c}{ Umidade $\left(\mathbf{c m}^{\mathbf{3}}\right.$ água/cm $\mathbf{c m}^{\mathbf{3}}$ solo) } \\
\hline $\mathbf{3 0 , 0} \mathbf{~ k P a}(\mathbf{C C})$ & 0,372 & 0,351 & 0,339 \\
$\mathbf{8 0 , 0} \mathbf{~ k P a}$ & 0,353 & 0,335 & 0,326 \\
\hline
\end{tabular}

\subsection{Sistema de irrigação}

A irrigação dos canteiros de rosas foi realizado através de um sistema de irrigação por gotejamento utilizando mangueira de polietileno com $12,5 \mathrm{~mm}$ de diâmetro e gotejadores tipo Katif com vazão de 2,3 $\ell . \mathrm{h}^{-1}$ e pressão de serviço de 10 m.c.a., espaçados de $0,3 \mathrm{~m}$ entre os gotejadores e $1,20 \mathrm{~m}$ entre as linhas de irrigação. As linhas de gotejadores mediam $7,0 \mathrm{~m}$ de comprimento, controladas por um registro de esfera conectado ao início de cada parcela.

As linhas laterais de irrigação foram interligadas em uma linha de derivação composta por uma mangueira de polietileno de $0,025 \mathrm{~m}$ de 
diâmetro, instaladas entre dois canteiros. A linha de derivação foi conectada a uma linha principal de $0,025 \mathrm{~m}$ com um registro de esfera para separar os canteiros do experimento do restante do bloco de estufas (Figura 3).

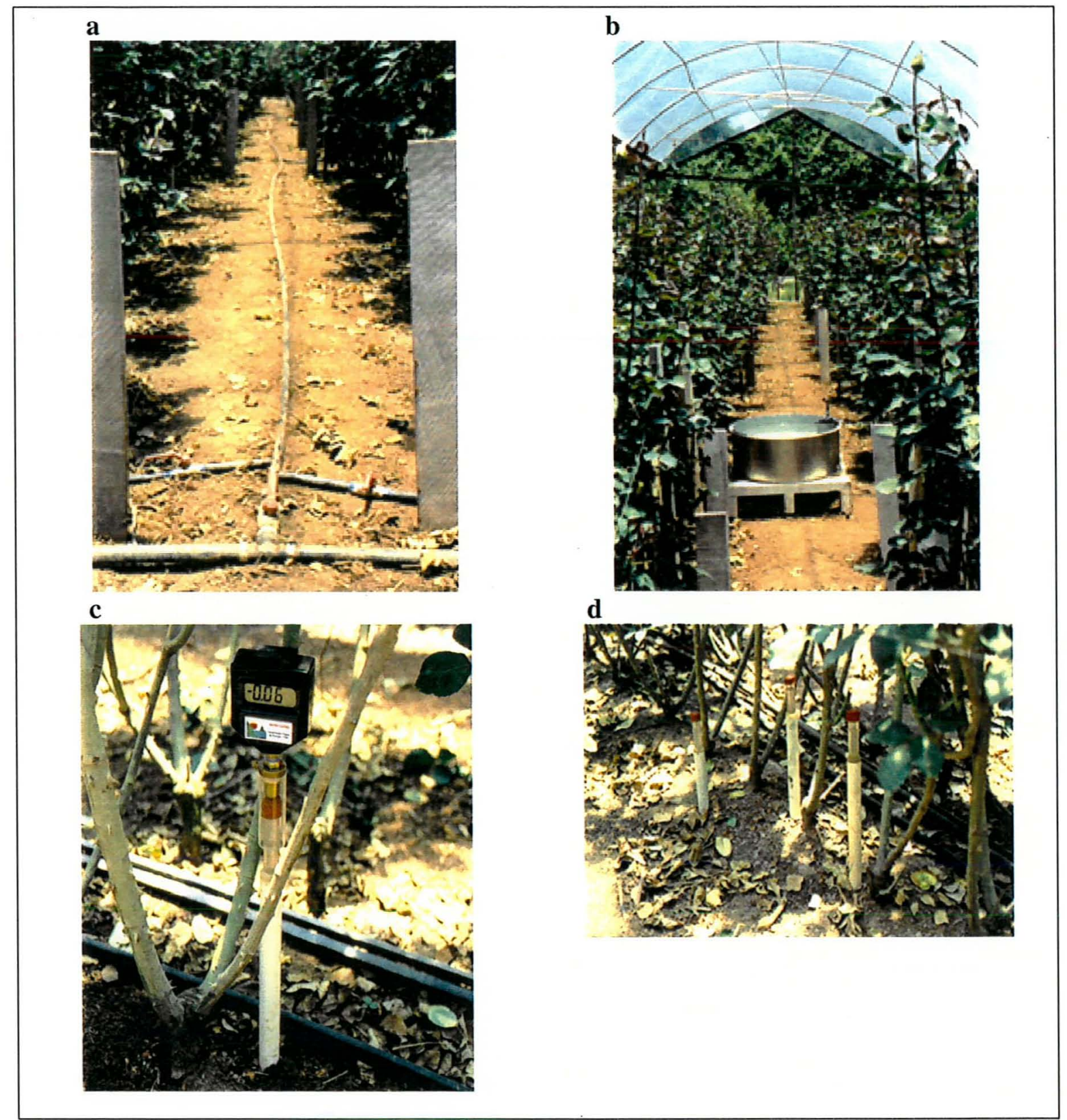

Figura 3. Vista geral do experimento: a) sistema de irrigação instalado com registro de esfera; b) tanque evaporimétrico reduzido; c) tensímetro digital de punção; d) bateria de tensiômetros instalados nas profundidades de 0,$10 ; 0,30$ e $0,50 \mathrm{~m}$. 


\subsection{Delineamento experimental}

O experimento iniciou no dia $14 / 10 / 99$ e terminou no dia 14/12/99. Foi conduzido em estufa plástica de $39,0 \mathrm{~m}$ de comprimento e 6,5 metros de largura totalizando 5 canteiros. $O$ delineamento experimental adotado foi de blocos casualizados conforme Nogueira (1994). Cada canteiro representava uma repetição com cinco tratamentos, perfazendo um total de 25 parcelas.

Cada parcela apresentava $0,95 \mathrm{~m}$ de largura e $5,0 \mathrm{~m}$ de comprimento totalizando uma área de $4,75 \mathrm{~m}^{2}$ com 50 plantas conduzidas por sistemas de podas. Entre as parcelas foi estipulado uma faixa de 2,0 m lineares como bordadura (Figura 4).

As lâminas de irrigação adotadas como tratamento foram determinadas da seguinte forma:

Tratamento T25 - fração de evaporação igual à $25 \%$ da lâmina medida no tanque reduzido.

Tratamento T50 - fração de evaporação igual à 50\% da lâmina medida no tanque reduzido.

Tratamento T75 - fração de evaporação igual à $75 \%$ da lâmina medida no tanque reduzido.

Tratamento T100 - fração de evaporação igual à $100 \%$ da lâmina medida no tanque reduzido.

Tratamento T125 - fração de evaporação igual à $125 \%$ da lâmina medida no tanque reduzido.

Para a análise dos resultados, foi utilizada a regressão polinomial, pois as lâminas de irrigação testadas constituíam em variáveis quantitativas. 


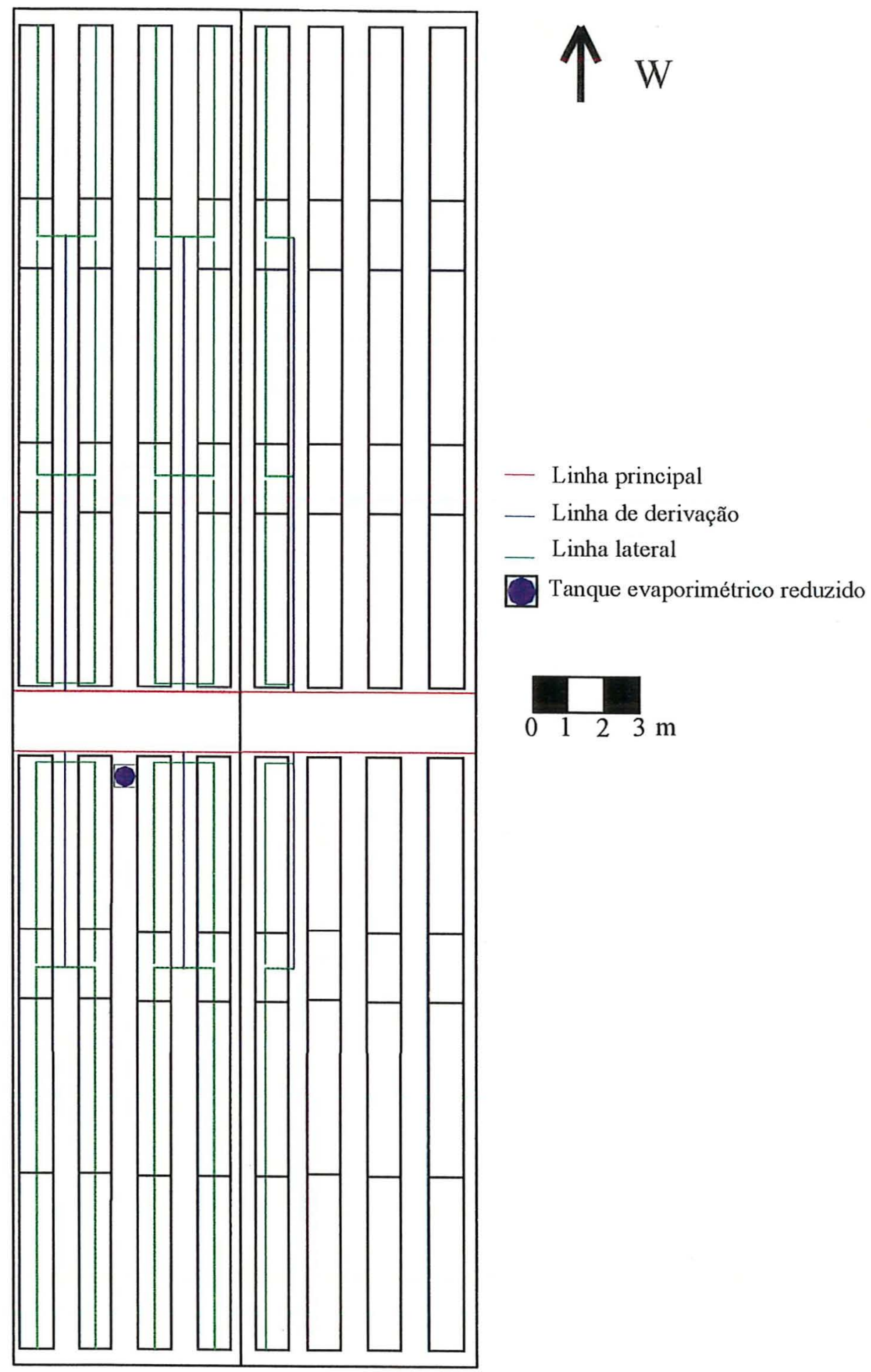

Figura 4. Croqui da área experimental. 


\subsection{Manejo da irrigação e fertirrigação}

O manejo da irrigação no interior da estufa foi realizado através de um tanque evaporimétrico reduzido, com $0,60 \mathrm{~m}$ de diâmetro e $0,25 \mathrm{~m}$ de altura colocado sobre um estrado de madeira a $0,15 \mathrm{~m}$ do solo, instalado entre dois canteiros de rosas, na parte mediana da estufa, para diminuir a influência do vento na evaporação do tanque (Figura3b).

As lâminas de irrigação foram calculadas baseando-se na somatória da evaporação do tanque reduzido (Evr) durante um intervalo de irrigação de dois dias e no fator " $f$ ", que representa a fração da evaporação do tanque reduzido dependendo do tratamento. As lâminas de irrigação a serem aplicadas foram calculadas de acordo com a expressão:

$$
h i=E v r \times f
$$

onde,

$\mathrm{h}_{\mathrm{i}}$ - Lâmina de irrigação( $\left.\mathrm{mm}\right)$

Evr - Evaporação do tanque reduzido no período

f - fração da evaporação do tanque reduzido (decimal), em função dos tratamentos.

As. lâminas de irrigação foram aplicadas de acordo com cada tratamento através de diferentes tempos de aplicação das linhas de gotejadores em cada parcela, calculado em função da vazão, do espaçamento entre gotejadores e do espaçamento entre as linhas, conforme a seguinte expressão:

$$
T i=\frac{h_{i} \times S_{g} \times S_{l}}{q \times E_{a}}
$$

onde, 
Ti - Tempo de irrigação para cada tratamento (h)

$h_{i}$ - Lâmina de irrigação a ser aplicada no tratamento (mm)

$\mathrm{S}_{\mathrm{g}}$ - Espaçamento entre gotejadores na linha de irrigação $(0,30 \mathrm{~m})$

$\mathrm{S}_{1}$ - Espaçamento entre linhas de gotejadores $(1,20 \mathrm{~m})$

$q$ - Vazão do gotejador $\left(2,3 \ell \cdot h^{-1}\right)$

$E_{a}-$ Efíciência de aplicação de água $(0,95)$

O monitoramento da água no solo foi efetuado através de 25 baterias de tensiômetros instalados em todas as parcelas nas profundidades de 0,$10 ; 0,30$ e $0,50 \mathrm{~m}$ (Figura $3 \mathrm{~d}$ ). As leituras foram realizadas através de um tensímetro digital de punção com precisão de $\pm 0,03 \%$ às $8: 30 \mathrm{~h}$ (Figura $3 \mathrm{c}$ ). Os valores de tensão foram utilizados para monitorar a umidade do solo em cada tratamento e estimar as perdas por drenagem profunda de água no solo de acordo com o método de Libardi (1984).

A fertirrigação foi realizada através de um injetor de fertilizante tipo Venturi acoplado em uma bomba centrifuga com potência de um cavalo vapor. A fertirrigação foi realizada através de duas fórmulas para evitar a incompatibilidade dos fertilizantes Nitrato de Cálcio com MonoAmônio-Fosfato . A fórmula A agrupava os macronutrientes ( $\mathrm{NPK}+\mathrm{Mg}$ ) (Tabela 4a) e micronutrientes (Tabela 4b) e a fórmula $B$ outros macronutrientes incluindo o cálcio (Tabela 5). A concentração dos nutrientes foi expresso em $\mathrm{mg} / \mathrm{l}$. Adotou-se uma freqüência de fertirrigação de dois dias, aplicando o mesmo tempo para todas as parcelas. A duração da fertirrigação foi baseada no tempo de irrigação do tratamento que aplicava a menor lâmina de irrigação. 
Tabela 4a. Concentrações de macronutrientes na fórmula $\mathrm{A}$.

\begin{tabular}{lccccc}
\hline \multicolumn{1}{c}{ Fertilizante } & \multicolumn{4}{c}{ Concentração dos nutrientes(mg/l) } \\
& $\mathbf{N H}_{\mathbf{4}}{ }^{+}$ & $\mathbf{N O}_{\mathbf{3}}{ }^{-}$ & $\mathbf{P}_{\mathbf{2}} \mathrm{O}_{\mathbf{5}}$ & $\mathbf{K}_{\mathbf{2}} \mathbf{O}$ & $\mathbf{M g}$ \\
\hline Nitrato de Amônio & 96,45 & 96,45 & & & \\
Nitrato de Potássio & & 60 & & 212,30 & \\
MAP & 11,85 & & 65,70 & \\
Sulfato de Magnésio & & & & 19 \\
\hline
\end{tabular}

Tabela 4b. Concentrações de micronutrientes na fórmula $\mathrm{A}$.

\begin{tabular}{cccccc}
\hline Fertilizante & \multicolumn{5}{c}{ Concentração dos nutrientes(mg/l) } \\
& Zn & Mn & Cu & B & Mo \\
\hline Sulfato de Zinco & 0,37 & & & & \\
Sulfato de Manganês & & 0,4 & & & \\
$\quad \begin{array}{c}\text { Sulfato de Cobre } \\
\text { Ácido Bórico }\end{array}$ & & & 0,60 & & \\
Molibdato de Sódio & & & & 0,18 & \\
\hline
\end{tabular}

Tabela 5. Concentração de macronutrientes na fórmula $B$.

\begin{tabular}{ccccc}
\hline \multirow{2}{*}{ Fertilizante } & \multicolumn{3}{c}{ Concentração dos nutrientes(mg/l) } \\
\cline { 2 - 5 } & $\mathrm{NH}_{4}{ }^{+}$ & $\mathrm{NO}_{3}{ }^{-}$ & $\mathrm{K}_{\mathbf{2}} \mathrm{O}$ & $\mathrm{Ca}$ \\
\hline Nitrato de Amônio & 109 & 109 & & \\
Nitrato de Potássio & & 90 & 318 & \\
Nitrato de Cálcio & & 50 & & 62 \\
\hline
\end{tabular}




\subsection{Parâmetros avaliados}

\subsubsection{Produção de hastes comerciais.}

A determinação da produção de rosas foi realizada por uma amostragem realizada durante o período de maior produção, que ocorreu no início do mês de dezembro. Para a contagem das hastes comerciais na parcela foi medido um metro linear dentro da parcela e extrapolado para as 50 plantas que correspondiam a área total parcela. A amostragem teve como objetivo quantificar as hastes retas e sem botão floral torto.

\subsubsection{Dimensões das hastes comerciais}

A medida do comprimento e diâmetro das hastes de rosas foram realizadas à partir de uma amostra de 15 hastes comerciais colhidas na parte central de cada parcela. O comprimento da haste foi mensurado entre o ponto de corte até o final do botão através de uma régua graduada em centímetros. O corte da roseira foi realizado na altura da $2^{a}$ ou $3^{a}$ folha de cinco folíolos da haste comercial. O diâmetro foi determinado na parte média da haste através de um paquímetro graduado em milímetros.

\subsubsection{Dimensões dos botões florais.}

A medida do comprimento e diâmetro dos botões florais foram determinados após a leitura do comprimento e diâmetro das hastes comerciais colhidas em cada parcela: O comprimento foi determinado à partir da base do botão e o diâmetro foi mensurado na parte mediana do botão através do paquímetro. 


\subsubsection{Massa fresca dos botões}

A massa fresca dos botões florais foi determinado através de uma balança digital com precisão de centésimo de grama, marca Marte, modelo AS 2000, logo após a determinação do comprimento e diâmetro dos botões.

\subsubsection{Massa seca dos botões}

Após a determinação da massa fresca, foram acondicionados em sacos de papel kraft para secagem em estufa, marca Marconi, modelo MA 037, dotadas de sistema de circulação e renovação de ar a um temperatura de $65^{\circ} \mathrm{C}$, até atingir peso constante. Após a secagem completa, o material foi pesado em balança analítica, marca Marte, modelo AS 2000, logo após da retirada da estufa para evitar a rehidratação da amostra

\subsection{6 Índice de área foliar}

Segundo modelo utilizado por Angelocci (1996), determinou-se o índice de área foliar (IAF) tomando-se uma planta por parcela e dividindo-se a área foliar da planta pela área ocupada no canteiro. Em cada planta foi contado o número de folhas e retirado uma amostra de $15 \%$ das folhas, onde foram medidas as dimensões dos eixos ortogonais, maior comprimento (C) e maior largura (L) de cada folíolo, calculando-se - valor médio para esses eixos. A área foliar para cada planta foi estimada pela fórmula:

$$
A F=K \times \bar{C} \times \bar{L} \times m
$$

onde,

C - comprimento médio do folíolo $(\mathrm{cm})$

L - largura média do folíolo $(\mathrm{cm})$

K - fator de correção

m - número total de folhas 
$O$ fator $\mathrm{K}$ foi estabelecido à partir de uma amostra de 50 folhas escolhidas ao acaso em várias plantas da estufa que não as da área experimental. A área das 50 folhas foi determinada após o traçado em papel milimetrado, sendo estas comparadas com o produto $\mathrm{C}$ x L obtendo o valor de $\mathrm{K}$.

O índice de área foliar (IAF) foi determinado através da expressão:

$$
I A F=\frac{A F}{A p l}
$$

onde,

IAF: Índice de Área Foliar $\left(\mathrm{m}^{2} / \mathrm{m}^{2}\right)$

AF: Área foliar da planta $\left(\mathrm{m}^{2}\right)$

Apl: Área ocupada pela planta na parcela $\left(0,95 \mathrm{~m}^{2}\right)$ 


\section{RESULTADOS E DISCUSSÃO}

\subsection{Evaporação do tanque evaporimétrico reduzido}

$\mathrm{Na}$ Figura 5, estão representadas as lâminas de irrigação acumuladas aplicadas nos tratamentos T25, T50, T75, T100 e T125, que correspondeu a 44,$5 ; 89,1 ; 133,6 ; 178,2$ e $222,7 \mathrm{~mm}$, respectivamente, observando-se uma variação entre a lâmina de irrigação máxima e mínima aplicada de $178,2 \mathrm{~mm}$.

A evaporação diária medida no tanque evaporimétrico reduzido durante o período em que foi realizado o experimento está representada na Figura 6. A menor evaporação observada foi de $0,2 \mathrm{~mm}$ no dia 18/10/99 e a maior evaporação observada foi de $6,68 \mathrm{~mm}$ no dia 01/11/99. A evaporação média medida durante todo o experimento foi de $2,83 \mathrm{~mm} \cdot \mathrm{dia}^{-1}$. As menores evaporações observadas ocorreram em dias nublados e com chuvas, e as maiores evaporações ocorreram em dias quentes e ensolarados.

Neste trabalho, a estufa não apresentava cortinas laterais, o que provavelmente contribuiu para o aumento da taxa de evaporação no interior do ambiente nos dias quentes e ensolarados. 


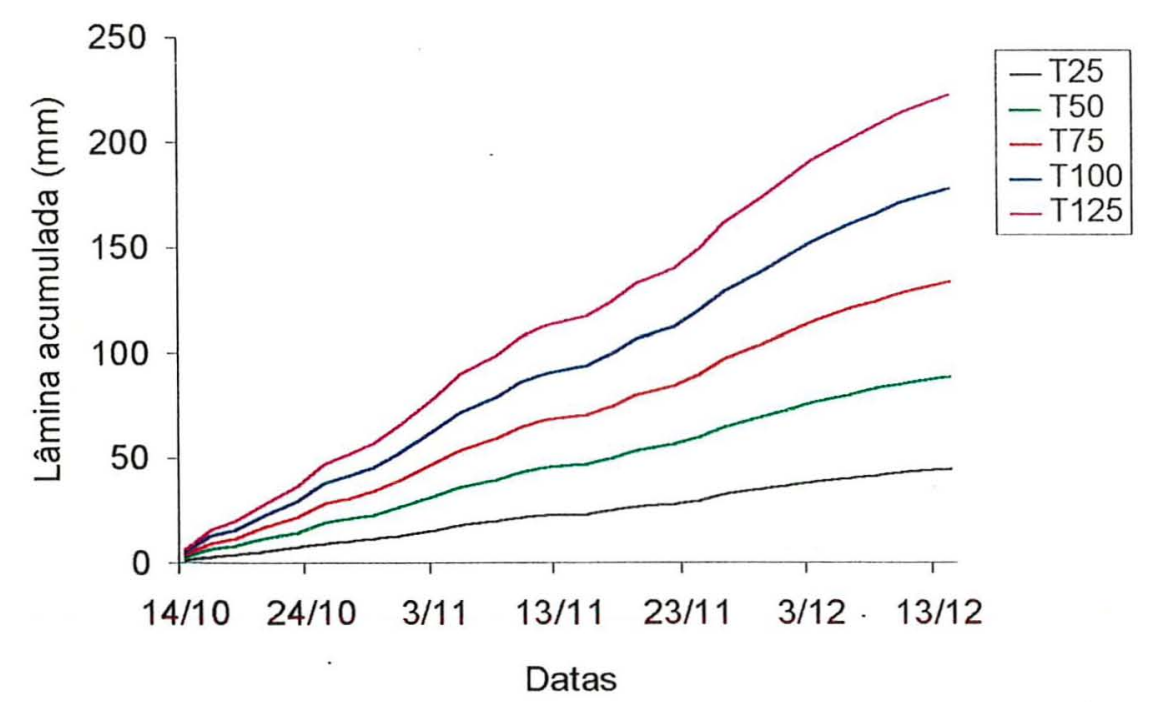

Figura 5. Lâminas de irrigação acumuladas aplicadas nos tratamentos, T25, T50, T75, T100 e T125 durante o experimento.

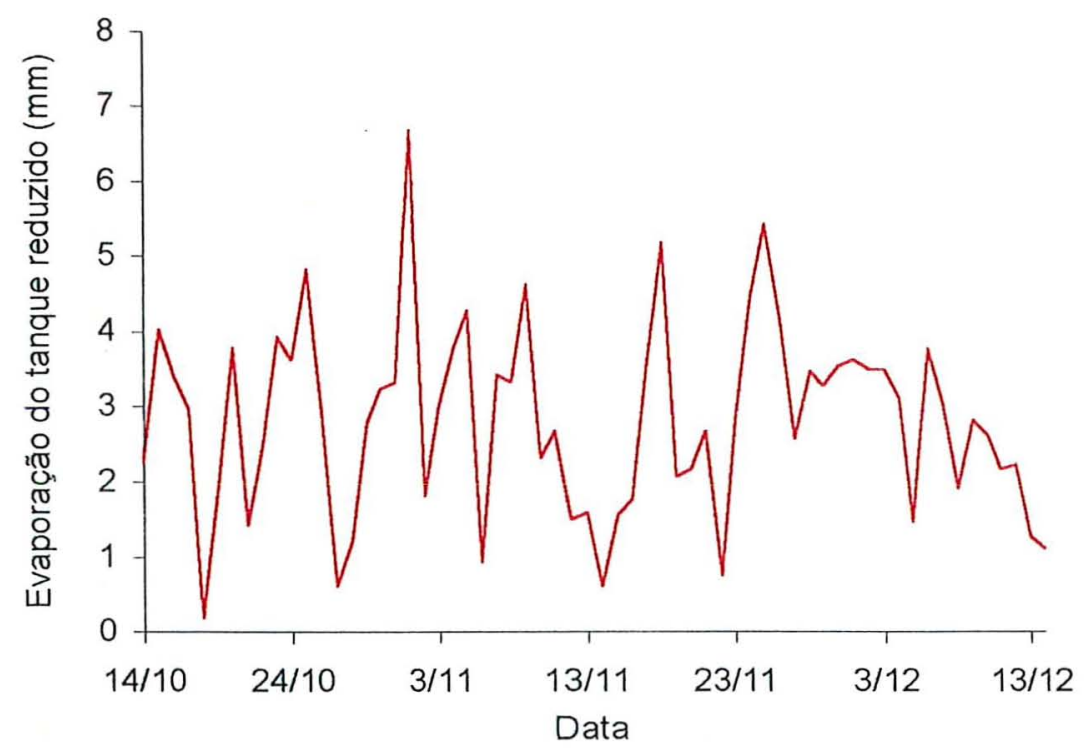

Figura 6. Evaporação diária medida no tanque evaporimétrico reduzido durante o experimento. 


\subsection{Parâmetros da flor}

Na Tabela 6 são apresentados os valores médios observados em cada tratamento para comprimento das hastes, diâmetro das hastes, comprimento dos botões, diâmetro dos botões, massa fresca dos botões florais e massa seca dos botões florais.

Tabela 6. Valores médios observados para comprimento das hastes (C.H.), diâmetro das hastes (D.H.), comprimento dos botões (C.B.), diâmetro dos botões (D.B.), massa fresca dos botões florais (M.F.B.) e massa seca dos botões florais (M.S.B.).

\begin{tabular}{cccccccc}
\hline $\begin{array}{c}\text { Tratamento } \\
\mathbf{f}^{*}\end{array}$ & $\begin{array}{c}\text { Lâm. } \\
\text { Aplic. } \\
\text { (m m) }\end{array}$ & $\begin{array}{c}\text { C. H. } \\
(\mathbf{c m})\end{array}$ & $\begin{array}{c}\text { D. H. } \\
(\mathbf{c m})\end{array}$ & $\begin{array}{c}\text { C. B. } \\
(\mathbf{c m})\end{array}$ & $\begin{array}{c}\text { D. B. } \\
(\mathbf{c m})\end{array}$ & $\begin{array}{c}\text { M.F.B. } \\
(\mathbf{g})\end{array}$ & $\begin{array}{c}\text { M.S.B. } \\
(\mathbf{g})\end{array}$ \\
\hline $\mathbf{T 2 5}$ & $\mathbf{4 4 , 5}$ & 63,38 & 0,626 & 4,52 & 2,523 & 7,87 & 1,65 \\
$\mathbf{T 5 0}$ & $\mathbf{8 9 , 1}$ & 65,79 & 0,617 & 4,61 & 2,556 & 8,22 & 1,70 \\
$\mathbf{T 7 5}$ & $\mathbf{1 3 3 , 6}$ & 66,73 & 0,627 & 4,58 & 2,630 & 8,03 & 1,68 \\
$\mathbf{T 1 0 0}$ & $\mathbf{1 7 8 , 2}$ & 71,57 & 0,637 & 4,75 & 2,608 & 8,77 & 1.72 \\
$\mathbf{T 1 2 5}$ & $\mathbf{2 2 2 , 7}$ & 70,09 & 0,676 & 4,78 & 2,667 & 8,84 & 1.75 \\
\hline
\end{tabular}

* Tratamentos referentes a fração de evaporação do tanque reduzido.

\subsubsection{Comprimento e diâmetro da haste}

A aplicação das lâminas de irrigação iniciou antes de ser efetuada a poda dos galhos que seriam avaliados. Com isto, a brotação e o desenvolvimento das hastes florais ocorreram sob influência das lâminas de irrigação aplicadas.

Os resultados médios obtidos na determinação do comprimento das hastes florais e ajustados pela regressão linear foram significativos a $5 \%$ pelo teste (Figura 7). Na Tabela 6 são apresentados os valores médios observados para comprimento das hastes, onde apresentaram valores de 
valores de 63,$38 ; 65,79 ; 66,73 ; 71,57$ e 70,09 $\mathrm{cm}$, que correspondeu aos tratamentos T25, T50, T75, T100 e T125, respectivamente. Em todas as parcelas, o comprimento das hastes apresentou valores médios acima de $60,0 \mathrm{~cm}$, apresentando valor mínimo de $60,44 \mathrm{~cm}$ e máximo de $78,04 \mathrm{~cm}$.

A comercialização das hastes de rosas é de acordo com a classificação do comprimento das hastes. Esta classificação é realizada na unidade produtora, separando as hastes de $40 ; 50 ; 60$ e $70 \mathrm{~cm}$. As hastes de $40 \mathrm{~cm}$ são classificadas como hastes curtas, as de $50 \mathrm{~cm}$, como hastes médias e as hastes de 60 e $70 \mathrm{~cm}$, como longas, obtendo preços maiores de acordo com seu comprimento.

A cultivar Osiana tem como característica a produção de hastes retas com comprimento acima de $60,0 \mathrm{~cm}$, como foi averiguado neste experimento, mas deve-se considerar que a aplicação de lâminas de irrigação abaixo da demanda hídrica da planta por períodos longos pode afetar o comprimento das hastes florais, produzindo hastes de comprimento curto, diminuindo a qualidade e conseqüentemente, a aceitação pelo mercado consumidor.

Estes resultados permitem observar uma relação entre o aumento do comprimento das hastes de acordo com o aumento da lâmina de irrigação aplicada. O mesmo não foi observado por Chimonidou-Pavlidou (1998) que trabalhou com rosas cultivadas em vasos de $0,30 \mathrm{~m}$ de diâmetro, onde aplicou a mesma lâmina de irrigação, determinada pelo tanque Classe $\mathrm{A}$, em diferentes intervalos de irrigação $(0,2,3$ e 6 dias), durante nove meses e observou que o comprimento das hastes foram significativamente menores, quando a planta foi submetida a um intervalo de irrigação de 6 dias durante o verão.

Apesar da brotação ter iniciado sob o efeito das diferentes lâminas de irrigação aplicadas, o comprimento das hastes no tratamento T25 foi estatisticamente igual aos tratamentos T50, T75, T100 e T125, entretanto, apresentaram aumento de 3,$8 ; 5,3 ; 12,3$ e $10,6 \%$, 
respectivamente, em relação ao tratamento $\mathrm{T} 25$. No trabalho realizado por Chimonidou-Pavlidou (1996), em que o estresse hídrico ocorreu na fase inicial da brotação, ou seja, na formação das primeiras folhas de cinco folíolos, foi observada uma redução no comprimento das hastes, comprimento dos botões e diâmetro dos botões, enquanto que o estresse aplicado em outras fases não resultou em redução significativa destes mesmos parâmetros.

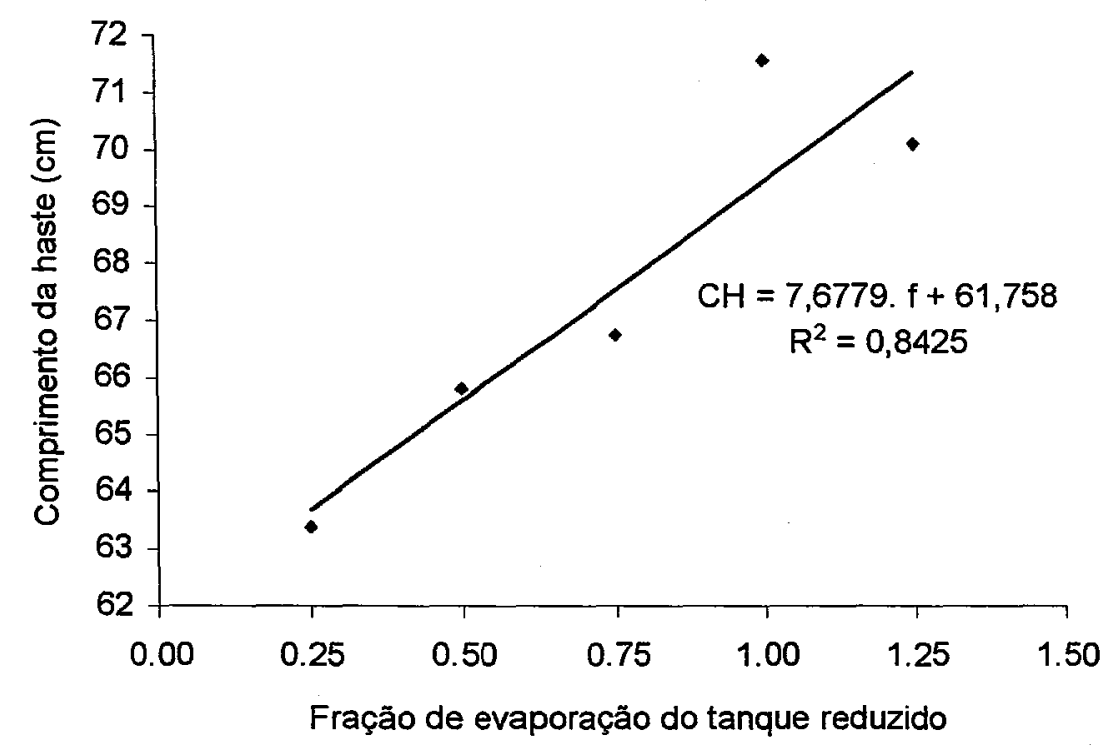

Figura 7. Relação entre fração de evaporação do tanque reduzido e comprimento médio das hastes florais.

Analisando o diâmetro das hastes florais, observa-se um comportamento semelhante ao do comprimento das hastes, havendo um aumento linear significativo a $5 \%$ pelo teste $F$ com coeficiente de determinação de 0,67 . Na Tabela 6 são apresentados os valores médios observados, evidenciando o aumento do diâmetro das hastes florais de acordo com o aumento da lâmina de irrigação aplicada, onde os resultados médios foram de 0,$62 ; 0,62 ; 0,63 ; 0,64$ e $0,67 \mathrm{~cm}$ para os tratamentos $\mathrm{T} 25, \mathrm{~T} 50, \mathrm{~T} 75, \mathrm{~T} 100$ e $\mathrm{T} 125$, respectivamente, representando um aumento de 3,2 e $8,0 \%$ do tratamento T100 e T125 em relação ao 
tratamento T25, respectivamente (Figura 8.). Urban et al. (1996), relatam que plantas sem estresse hídrico apresentam maior crescimento das células, refletindo em maior diâmetro das hastes e altura da planta.

Em todos os tratamentos, os valores médios observados para diâmetro das hastes florais foram maiores que $0,60 \mathrm{~cm}$. Hastes com este diâmetro apresentam maior qualidade das hastes obtendo maior durabilidade após a colheita, aumentando a aceitação pelo mercado consumidor, obtendo preços melhores.

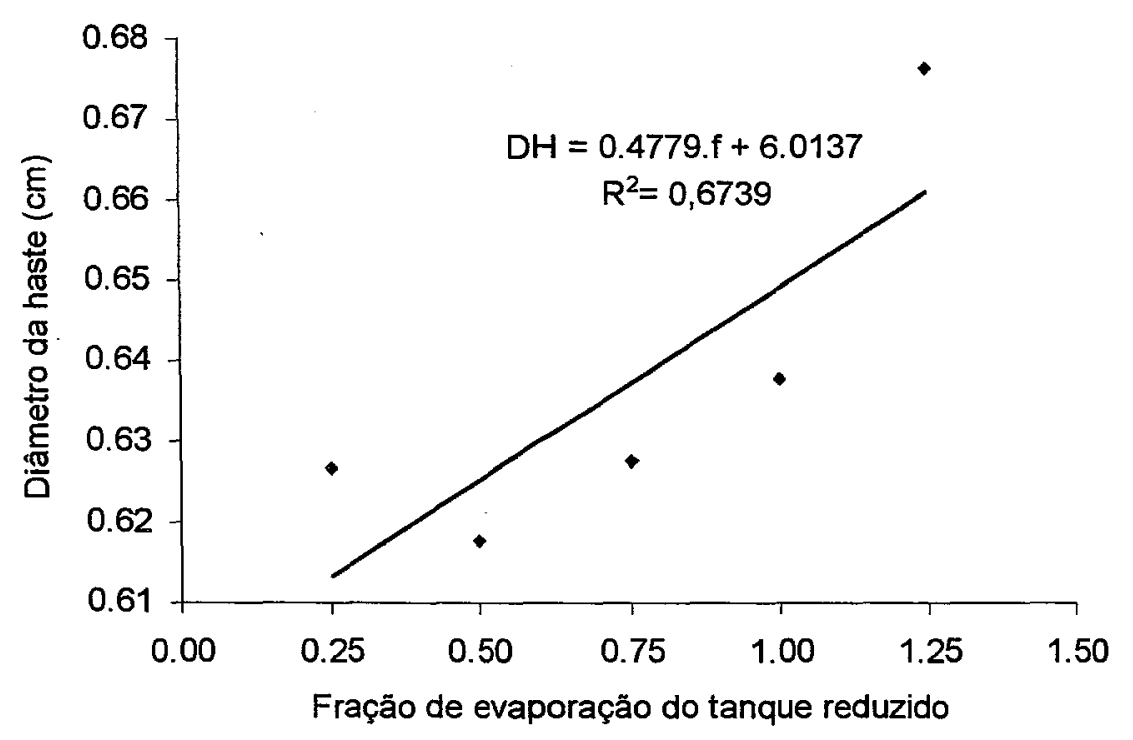

Figura 8. Relação entre fração de evaporação do tanque reduzido e o diâmetro das hastes florais.

\subsubsection{Comprimento e diâmetro dos botões florais}

A análise dos valores médios observados para o comprimento e diâmetro dos botões florais foram significativos à $5 \%$ pelo teste $\mathrm{F}$, apresentando aumento linear das variáveis de acordo com o aumento das lâminas de irrigação aplicadas.

$\mathrm{Na}$ análise do comprimento dos botões florais, as médias observadas foram de 4,$52 ; 4,61 ; 4,58,4,75$ e $4,78 \mathrm{~cm}$ para os tratamentos $\mathrm{T} 25, \mathrm{~T} 50, \mathrm{~T} 75, \mathrm{~T} 100$ e $\mathrm{T} 125$, respectivamente, apresentando um aumento 
de $5,8 \%$ do tratamento T125 em relação a T25 (Tabela 6). Na Figura 9, está representada a relação entre o aumento do comprimento dos botões florais e as frações de evaporação do tanque reduzido, com um coeficiente de determinação de 0,87 .

A análise de regressão entre o diâmetro do botão floral e a fração de evaporação do tanque reduzido apresentou um aumento linear significativo com um coeficiente de determinação de 0,87 (Figura 10). Os valores médios observados foram de 2,$52 ; 2,55 ; 2,63 ; 2,61$ e 2,67 cm para os tratamentos T25, T50, T75, T100 e T125, respectivamente, correspondendo a um aumento máximo no tratamento $\mathrm{T} 125 \mathrm{em}$ relação ao tratamento T25 de 5,95\% (Tabela 6).

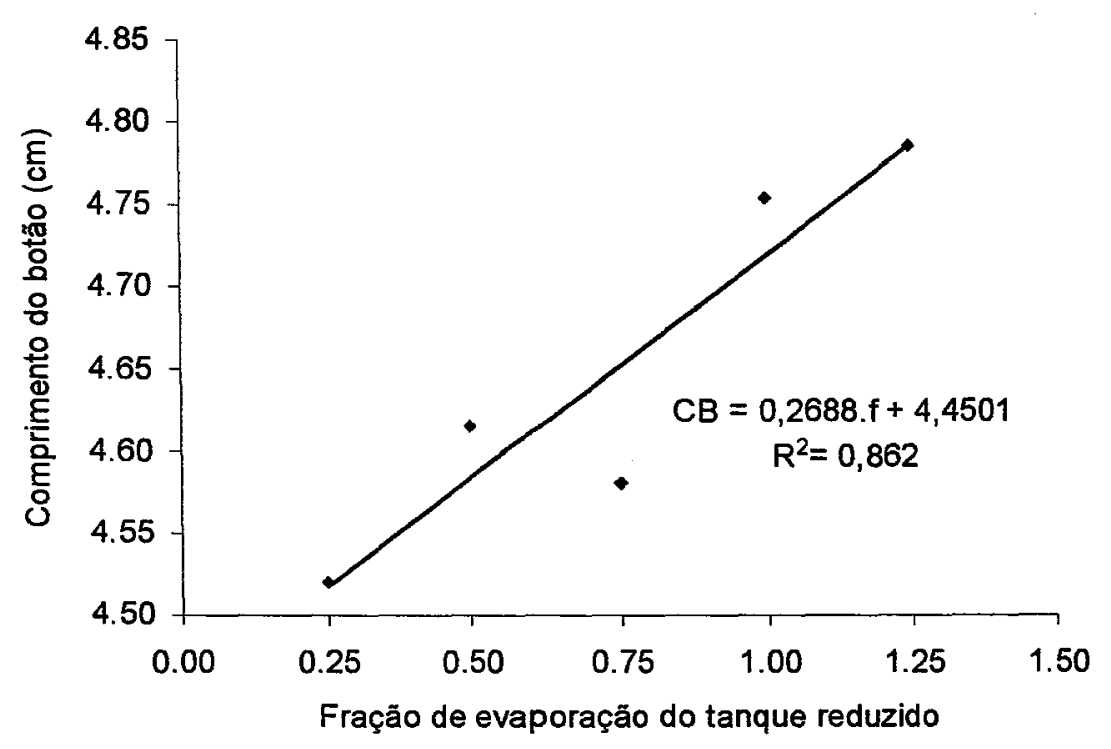

Figura 9. Relação entre a fração de evaporação do tanque reduzido e o comprimento dos botões florais. 




Figura 10. Relação entre a fração de evaporação do tanque reduzido e o diâmetro dos botões florais.

\subsubsection{Massa fresca e massa seca dos botões florais}

Verificando-se os valores médios de massa fresca dos botões florais, observou-se um aumento linear da massa fresca em relação às lâminas de irrigação, apresentando um coeficiente de determinação de 0,81 (Figura 11). Os valores médios para os tratamentos T25, T50, T75, T100 e T125 foram de 7,$87 ; 8,22 ; 8,03 ; 8,77$ e $8,85 \mathrm{~g}$, respectivamente (Tabela 6). O aumento na massa fresca dos botões florais foi 4,$45 ; 2,0$; 11,44 e $12,45 \%$ para os tratamentos T50, T75, T100 e T125, respectivamente, em relação ao tratamento T25.

Neste ensaio, não foi utilizada nenhuma técnica visando aumentar a umidade relativa do ar no interior do ambiente protegido, pois a ocorrência de Botrytis spp. devido ao aumento da umidade relativa do ar poderia prejudicar o desenvolvimento dos botões florais. Entretanto, a adequada umidade relativa do ar no interior da estufa, pode melhorar a qualidade das hastes. Plaut et al. (1979), obteve aumento na massa fresca 
dos botões com o uso de sistema "pad and fan", elevando a umidade relativa do ar no interior da estufa.

$\mathrm{Na}$ Figura 12, está representado a relação entre a fração de evaporação do tanque reduzido e a massa seca dos botões florais com um coeficiente de determinação de 0,70 (Figura 12). Os valores médios observados foram de 1,$65 ; 1,70 ; 1,68 ; 1,72$ e $1,75 \mathrm{~g}$ para os tratamentos T25, T50, T75, T100 e T125, respectivamente. Na análise da massa seca dos botões florais verificou-se um acréscimo de 4,24 e $6,1 \%$ dos tratamentos $\mathrm{T} 100$ e $\mathrm{T} 125$ em relação ao tratamento $\mathrm{T} 25$, respectivamente (Tabela 6).

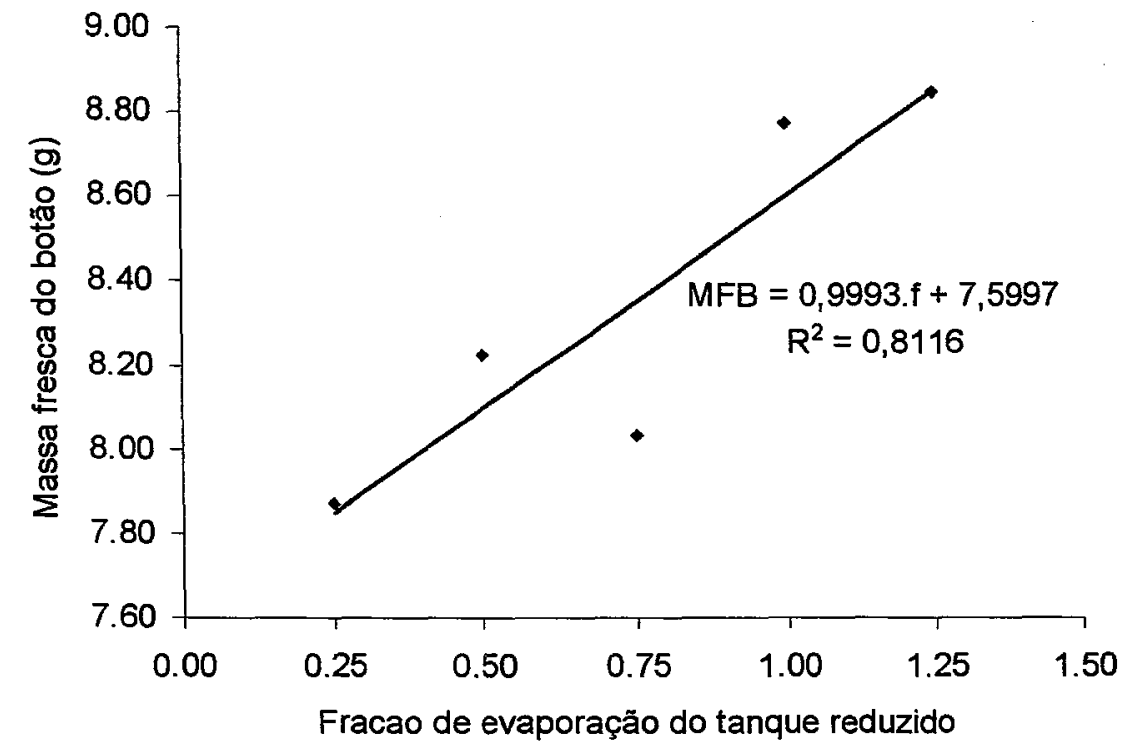

Figura 11. Relação entre a fração de evaporação do tanque reduzido e a massa fresca dos botões florais. 


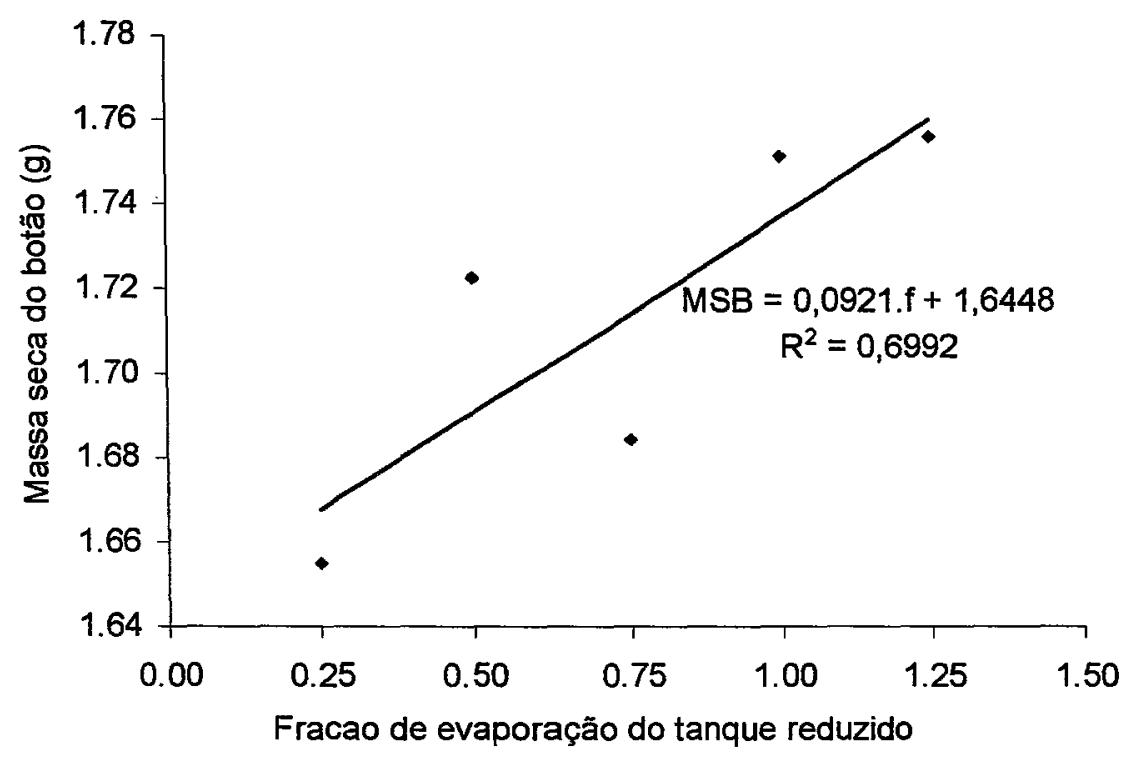

Figura 12. Relação entre a fração de evaporação do tanque reduzido e a massa seca dos botões florais.

\subsection{Produtividade das hastes florais}

A avaliação da produtividade foi realizada em cada parcela, contando-se o número de hastes produzidas em um metro linear, tomados na parte central da parcela e extrapolado para o número total de plantas da parcela.

A análise de regressão entre a produtividade e a fração de evaporação do tanque reduzido foi significativo à $5,0 \%$ pelo teste $F$, apresentando um ajuste quadrático, com coeficiente de determinação igual a 0,98 (Figura 13). Os valores médios observados são apresentados na Tabela 7, onde as lâminas de irrigação aplicadas correspondentes aos tratamentos $\mathrm{T} 25, \mathrm{~T} 50, \mathrm{~T} 75, \mathrm{~T} 100$ e $\mathrm{T} 125$ apresentaram produtividades médias de $80 ; 114 ; 134 ; 136$ e 146 hastes/parcela, respectivamente. 0 aumento na produtividade para os tratamentos T50, T75, T100 e T125 foram de 42,$5 ; 67,5 ; 70,0$ e $82,5 \%$ em relação ao tratamento $\mathrm{T} 25$, respectivamente. 
Considerando um total de 70.000 plantas/hectare, a produtividade média obtida nas parcelas submetidas à maior lâmina de irrigação correspondeu a $17.033 \mathrm{dz} / \mathrm{ha}$, enquanto que para a menor lâmina, a produtividade média foi de $9.333 \mathrm{dz} / \mathrm{ha}$. A diferença foi de $7.700 \mathrm{dz} / \mathrm{ha}$ de rosas durante o período de maior produção. Em relação aos tratamentos T50, T75 e T100, a diferença foi de $3.967 ; 6.300$ e $6.334 \mathrm{dz} / \mathrm{ha}$, respectivamente.

Tabela 7. Valores médios do índice de área foliar (IAF) e da produtividade em cada tratamento.

\begin{tabular}{cccc}
\hline $\begin{array}{c}\text { Fração de } \\
\text { evaporação }\end{array}$ & $\begin{array}{c}\text { Lâmina } \\
\text { aplicada }(\mathbf{m m})\end{array}$ & $\begin{array}{c}\text { IAF } \\
\left(\mathbf{m}^{\mathbf{2}} / \mathbf{m}^{\mathbf{2}}\right)\end{array}$ & $\begin{array}{c}\text { Produtividade } \\
\text { (hastes/parcela) }\end{array}$ \\
\hline 0,25 & 44,5 & 0,734 & 80 \\
0,50 & 89,1 & 0,999 & 114 \\
0,75 & 133,6 & 1,571 & 134 \\
1,00 & 178,2 & 2,137 & 136 \\
1,25 & 222,7 & 2,256 & 146 \\
\hline
\end{tabular}

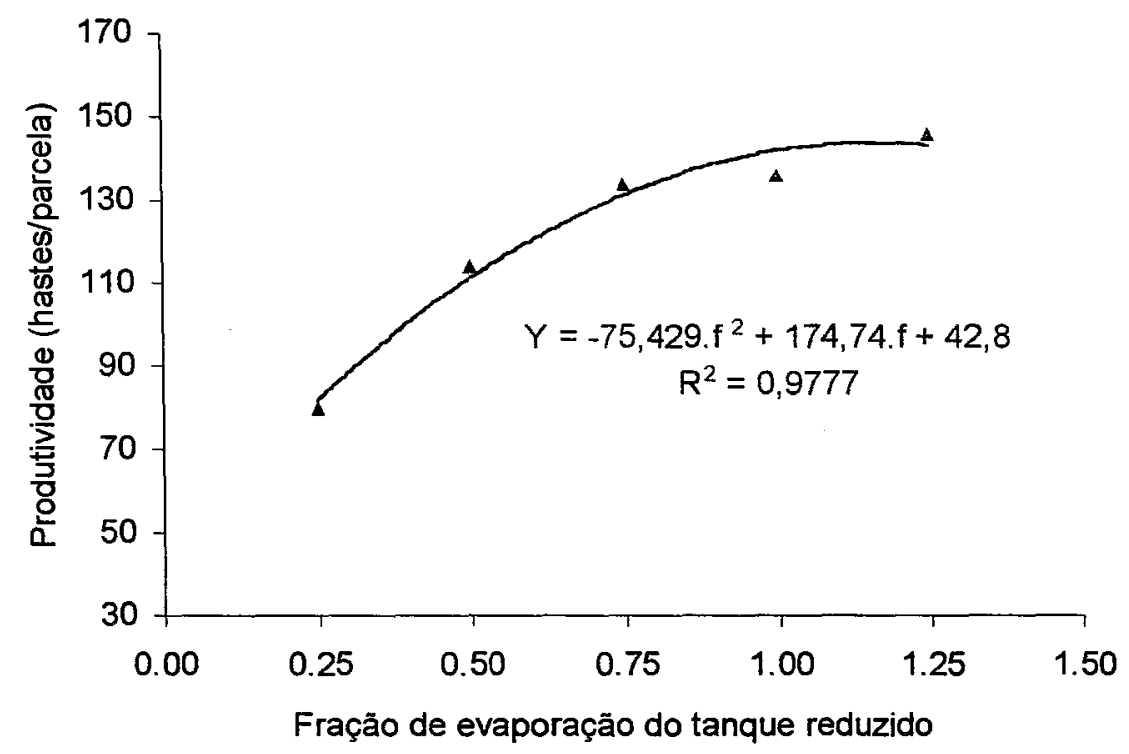

Figura 13. Relação entre a fração de evaporação do tanque reduzido e a produtividade das hastes florais. 
À partir da equação apresentada na Figura 13, representando a relação entre as lâminas de irrigações aplicadas de acordo com os tratamentos e a produtividade da roseira cultivada em ambiente protegido, observa-se que uma fração de evaporação igual a 1,15 corresponde a uma produtividade máxima de 144 hastes/parcela.

Com os resultados de comprimento e diâmetro das hastes, comprimento, diâmetro, massa fresca e massa seca dos botões florais e produtividade das hastes, concluiu-se que o manejo da irrigação em ambiente protegido utilizando tanque evaporimétrico reduzido pode auxiliar o produtor na aplicação da quantidade correta de água para as plantas, ocupando espaço reduzido no interior da estufa, diminuindo gastos com energia elétrica, água e fertilizantes, obtendo qualidade das hastes e botões florais em um aumento na produtividade e lucratividade.

\subsection{Eficiência do uso da água pela cultura da rosa}

A ótima irrigação é aquela que economiza água sem reduzir a produtividade (Stanhill \& Vaadia, 1967), entretanto, o uso eficiente da água pelas culturas agrícolas depende das condições físicas do solo, das condições atmosféricas, do estado nutricional das plantas, de fatores físiológicos, da natureza genética e de seu estádio de desenvolvimento Calvache eta al. (1997).

A eficiência do uso da água pode ser avaliada de várias maneiras, entre elas, a relação entre produtividade e a quantidade de água aplicada. $\mathrm{Na}$ Tabela 8, são apresentados os valores de eficiência do uso da água na cultura da roseira para cada tratamento. Observou-se que a eficiência de uso da água decresceu de acordo com o aumento das lâminas de irrigação aplicadas, entretanto os tratamentos com as maiores eficiências tiveram a produtividade e a qualidade das hastes e botões afetados. Nos tratamentos T100 e T125 a quantidade de água aplicada foi quatro e cinco vezes 
maiores que o tratamento $\mathrm{T} 25$, entretanto a produtividade foi 70,0 e $82,5 \%$ maiores, respectivamente.

Tabela 8. Eficiência do uso da água na cultura da rosa.

\begin{tabular}{cccc}
\hline Tratamento & $\begin{array}{c}\text { Produtividade } \\
\text { (dz/ha) }\end{array}$ & $\begin{array}{c}\text { Lâmina aplicada } \\
\left(\mathbf{m}^{\mathbf{3}} / \mathbf{h a}\right)\end{array}$ & $\begin{array}{c}\text { Eficiência } \\
\left(\mathbf{d z} / \mathbf{m}^{\mathbf{3}}\right)\end{array}$ \\
\hline T25 & 9.333 & 445 & 21,02 \\
T50 & 13.300 & 891 & 14,93 \\
T75 & 15.633 & 1336 & 11,70 \\
T100 & 15.867 & 1782 & 8,90 \\
T125 & 17.033 & 2227 & 7,65 \\
\hline
\end{tabular}

\section{5 Índice de área foliar (IAF)}

A análise do IAF em função dos tratamentos apresentou uma relação linear com coeficiente de determinação de 0,97 , entre a fração de evaporação do tanque reduzido e o IAF (Figura 14).

Os valores médios do IAF foram de 0,$73 ; 0,99 ; 1,57 ; 2,14$ e 2,25 para os tratamentos $\mathrm{T} 25, \mathrm{~T} 50, \mathrm{~T} 75, \mathrm{~T} 100$ e $\mathrm{T} 125$, respectivamente (Tabela 7). Com este resultado observou-se que nos tratamentos T50, T75, T100 e T125 ocorreu um incremento de 36,$1 ; 114,0 ; 191,1$ e $207,4 \%$, respectivamente, em relação ao tratamento T25. O aumento no IAF nos tratamentos T75, T100 e T125 ocorreu devido a maior disponibilidade de água na zona de maior concentração de raízes.

Comparando os resultados médios do IAF com os de produtividade média, ajustou-se uma regressão polinomial de segundo grau obtendo um coeficiente de determinação de 0,94 . Constatou-se que o aumento de $207,4 \%$ no IAF correspondeu a um aumento de $82,5 \%$ na produtividade. $O$ maior $o$ número de folhas, maior atividade fotossintética e a maior produção de assimilados resultou em maior produtividade e qualidade das hastes e botões florais. 


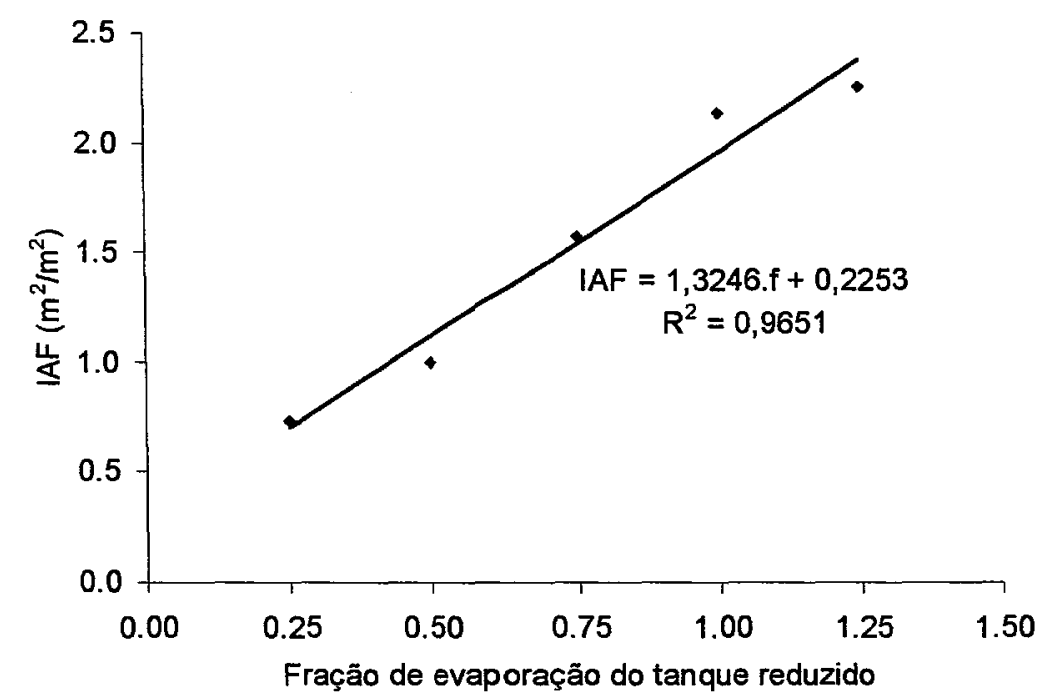

Figura 14. Variação do IAF em função das frações de evaporação do tanque reduzido.

Derivando-se a função de produção representada pela Figura 15, observou-se que a produtividade atinge um ponto de máxima quando o IAF alcança o valor de 1,57, correspondendo a uma produtividade de 143 hastes/parcela.



Figura 15. Relação entre IAF e produtividade de haste/parcela. 


\subsection{Potencial matricial da água no solo}

Foram realizadas leituras em tensiômetros instalados nas parcelas, a fim de avaliar a variação do potencial matricial da água no solo na região do sistema radicular das plantas (Figura 3d).

Os resultados mostraram que o potencial da água no solo elevouse de acordo com o aumento das frações de evaporação do tanque reduzido durante a condução do experimento.

Na Tabela 9, são apresentados os valores máximos, mínimos e médios do potencial matricial da água no solo para cada tratamento e profundidade, observados durante todo o período experimental. Devido a maior evaporação da camada superficial, os valores médios do potencial matricial da água no solo na profundidade de $0,10 \mathrm{~m}$ foram menores para os tratamentos T25, T50 e T75, obtendo-se valores médios de -62,5; $-54,4$ e $-47,8 \mathrm{kPa}$, respectivamente. Nos tratamentos T100 e T125, os potenciais matriciais da água no solo foram maiores, resultando em médias de $-25,6$ e $-29,4 \mathrm{kPa}$, respectivamente. Na Figura 16, está representada a relação entre as frações de evaporação com os valores médios de potencial matricial, observando o aumento do potencial matricial de acordo com o aumento das lâminas de irrigação aplicadas nos tratamentos. 


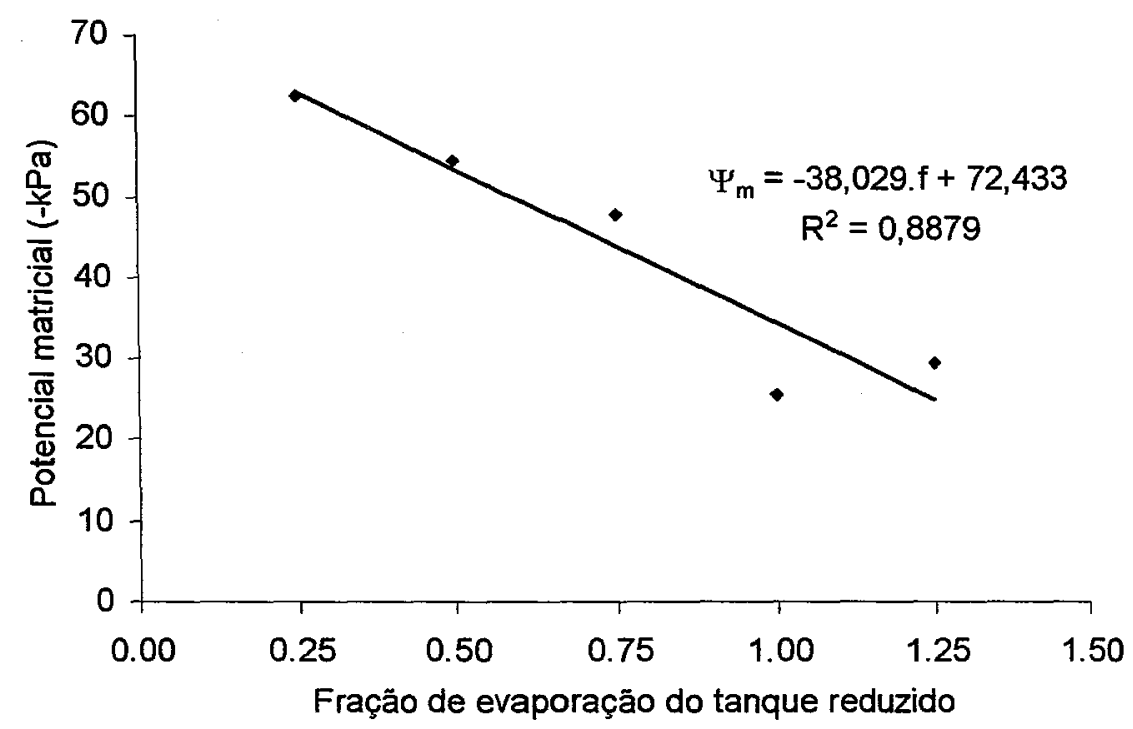

Figura 16. Variação do potencial matricial de água no solo em função das frações de evaporação do tanque reduzido na profundidade de $0,10 \mathrm{~m}$.

$\mathrm{Na}$ profundidade de $0,30 \mathrm{~m}$, o potencial matricial da água no solo aumentou em função das frações de evaporação utilizadas, obtendo valores médios de $-56,7 ;-26,1 ;-16,1 ;-13,8$ e $-6,2 \mathrm{kPa}$ nos tratamentos T25, T50, T75, T100 e T125, respectivamente. Na Figura 17, está representada esta relação, onde ajustou-se uma regressão de segundo grau demonstrando o aumento do potencial matricial da água no solo devido o aumento das frações de evaporação do tanque reduzido. O potencial matricial médio de $-56,7 \mathrm{kPa}$, medido no tratamento $\mathrm{T} 25$, revela que a água aplicada na profundidade de $0,30 \mathrm{~m}$ foi consumida pelas plantas, permanecendo em níveis mais baixos durante o experimento. 


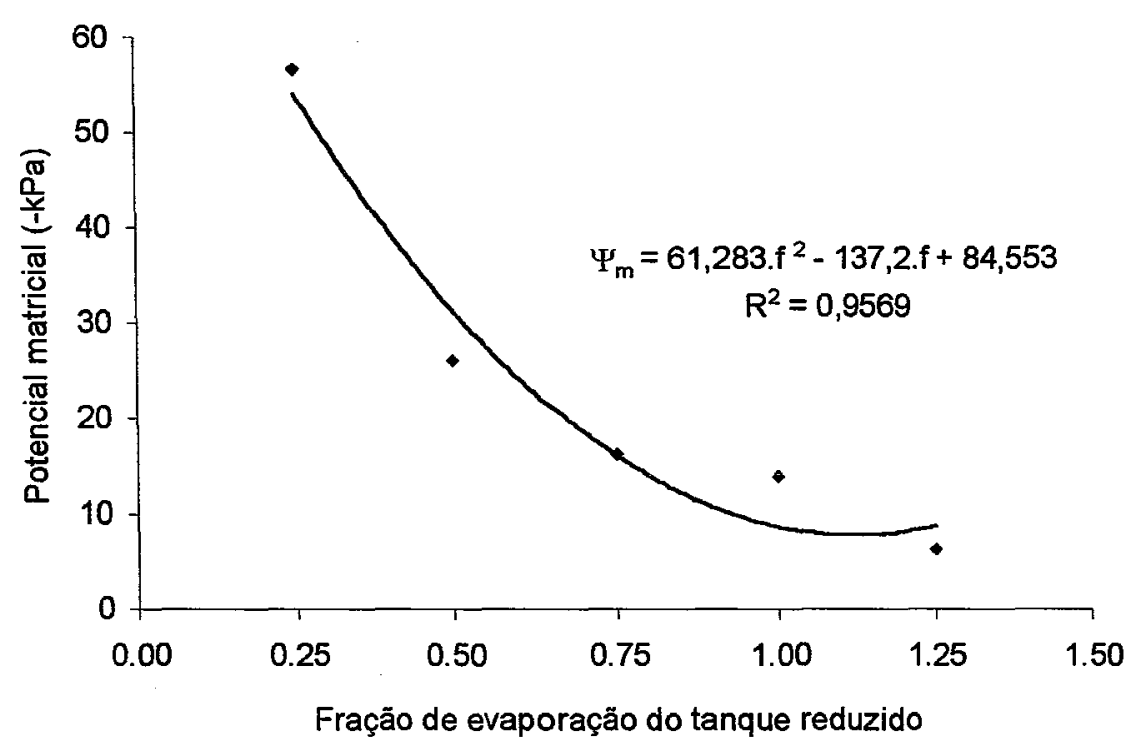

Figura 17. Variação do potencial matricial de água no solo em função das frações de evaporação do tanque reduzido na profundidade de $0,30 \mathrm{~m}$.

$\mathrm{Na}$ profundidade de $0,50 \mathrm{~m}$, os valores médios de potencial matricial de água no solo elevaram-se até o tratamento $\mathrm{T} 75$, observando valores médios de $-52,8 ;-32,8$ e $-11,9 \mathrm{kPa}$ para os tratamentos $\mathrm{T} 25$, T50 e T75, respectivamente. Nos tratamentos T100 e T125, os valores médios de potencial matricial de água no solo diminuiram para $-20,2$ e $-24,2$ $\mathrm{kPa}$, respectivamente (Figura 17). O aumento dos valores médios de potencial matricial de água no solo nos tratamentos T100 e T125 deve-se a maior absorção de água pelas plantas nas camadas superiores, pois as plantas apresentaram maior IAF, produtividade, qualidade das hastes e dos botões florais. 




Figura 18. Variação do potencial matricial de água no solo em função das frações de evaporação do tanque reduzido na profundidade de $0,50 \mathrm{~m}$.

Tabela 9. Valores máximos, mínimos e médios do potencial matricial $(\mathrm{kPa})$ de água no solo para cada tratamento.

\begin{tabular}{ccccc}
\hline Tratamentos & Prof.(m) & Máximo & Mínimo & Média geral \\
\hline \multirow{2}{*}{ T25 } & $\mathbf{0 , 1 0}$ & $-76,2$ & $-47,6$ & $-62,5$ \\
& $\mathbf{0 , 3 0}$ & $-82,4$ & $-24,8$ & $-56,7$ \\
& $\mathbf{0 , 5 0}$ & $-77,4$ & $-26,0$ & $-52,8$ \\
\hline \multirow{2}{*}{ T50 } & $\mathbf{0 , 1 0}$ & $-79,0$ & $-20,4$ & $-54,4$ \\
& $\mathbf{0 , 3 0}$ & $-63,0$ & $-5,2$ & $-26,1$ \\
& $\mathbf{0 , 5 0}$ & $-54,2$ & $-9,4$ & $-32,8$ \\
\hline \multirow{2}{*}{ T75 } & $\mathbf{0 , 1 0}$ & $-70,8$ & $-25,6$ & $-47,8$ \\
& $\mathbf{0 , 3 0}$ & $-48,8$ & $-4,0$ & $-16,1$ \\
& $\mathbf{0 , 5 0}$ & $-27,2$ & $-3,2$ & $-11,9$ \\
\hline \multirow{2}{*}{ T100 } & $\mathbf{0 , 1 0}$ & $-53,2$ & $-3,8$ & $-25,6$ \\
& $\mathbf{0 , 3 0}$ & $-46,4$ & $-2,4$ & $-13,8$ \\
& $\mathbf{0 , 5 0}$ & $-42,0$ & $-4,8$ & $-20,2$ \\
\hline \multirow{2}{*}{ T125 } & $\mathbf{0 , 1 0}$ & $-66,0$ & $-6,0$ & $-29,4$ \\
& $\mathbf{0 , 3 0}$ & $-35,0$ & $-1,0$ & $-6,2$ \\
& $\mathbf{0 , 5 0}$ & $-43,2$ & $-9,8$ & $-24,2$ \\
\hline
\end{tabular}




\subsubsection{Potencial matricial versus IAF}

$\mathrm{Na}$ Tabela 10 , observa-se os valores médios de potencial matricial da água no solo e o IAF para cada tratamento. Relacionando os valores médios de potencial matricial de água no solo com o IAF, na profundidade de $0,10 \mathrm{~m}$, verificou-se uma redução de $67,5 \%$ no IAF quando o potencial matricial da água no solo decresceu de $-29,4 \mathrm{kPa}$ para $-62,5 \mathrm{kPa}$ (Figura 19). $\mathrm{Na}$ profundidade de $0,30 \mathrm{~m}$ o mesmo ocorreu, entretanto de uma forma gradual, permitindo ajustar um polinômio de segundo grau com coeficiente de determinação igual à 0,91 (Figura 20.). Verificou-se nesta profundidade que os valores médios de potencial matricial de água no solo para os tratamentos T25, T50, T75, T100 e T125 foram de $-56,7 ;-26,1 ;-16,1 ;-13,8$ e $-6,2 \mathrm{kPa}$, correspondendo a IAF de 0,$73 ; 0,99 ; 1,57 ; 2,13$ e 2,25 , respectivamente.

Tabela 10. Valores médios de potencial matricial de água no solo e IAF para cada fração de evaporação de água no solo.

\begin{tabular}{ccccc}
\hline Fraç̃o de evaporação & $\mathbf{1 0} \mathbf{~ c m}$ & $\mathbf{3 0} \mathbf{~ c m}$ & $\mathbf{5 0} \mathbf{~ c m}$ & IAF \\
\hline $\mathbf{0 , 2 5}$ & $-62,5$ & $-56,7$ & $-52,8$ & 0,734 \\
$\mathbf{0 , 5 0}$ & $-54,4$ & $-26,1$ & $-32,8$ & 0,999 \\
$\mathbf{0 , 7 5}$ & $-47,8$ & $-16,1$ & $-11,9$ & 1,571 \\
$\mathbf{1 , 0 0}$ & $-25,6$ & $-13,8$ & $-20,2$ & 2,137 \\
$\mathbf{1 , 2 5}$ & $-29,4$ & $-6,2$ & $-24,2$ & 2,256 \\
\hline
\end{tabular}






Figura 19. Relação entre potencial matricial de água no solo e IAF na profundidade de $0,10 \mathrm{~m}$.

Na Figura 21, está representada a relação entre potencial matricial - de água no solo e IAF para a profundidade de $0,50 \mathrm{~m}$. O potencial matricial de água no solo diminuiu nos tratamentos T100 e T125, apresentando valores médios de $-20,2$ e $-24,2 \mathrm{kPa}$, respectivamente. Mesmo assim, os valores médios de potencial matricial ficaram acima do potencial matricial na capacidade de campo, que é de $-30,0 \mathrm{kPa}$ para solo argiloso. Os valores médios de IAF foram 2,13 e 2,25, respectivamente, pois estes tratamentos foram os que apresentaram melhores resultados em todos os parâmetros avaliados. 


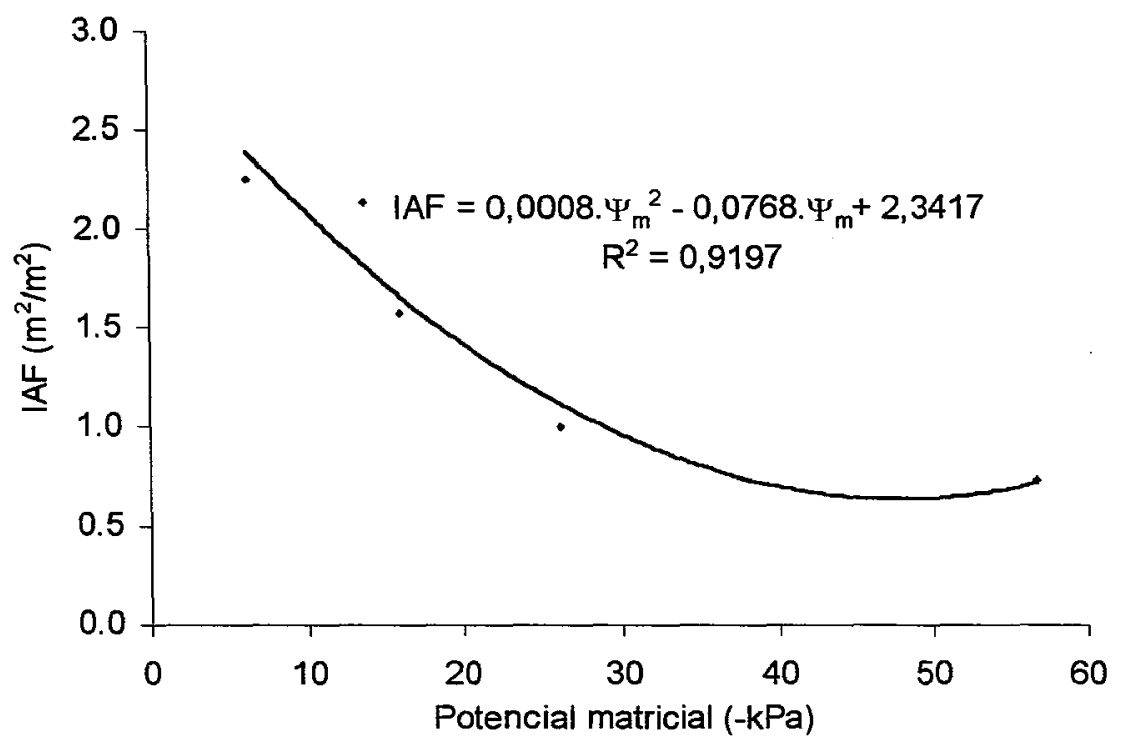

Figura 20. Relação entre potencial matricial de água no solo e IAF na profundidade de $0,30 \mathrm{~m}$.



Figura 21. Relação entre potencial matricial de água no solo e o IAF na profundidade de $0,50 \mathrm{~m}$. 


\subsubsection{Potencial matricial versus produtividade de hastes}

A partir dos resultados médios de produtividade e do potencial matricial da água no solo para as profundidades de 0,$10 ; 0,30$ e $0,50 \mathrm{~m}$ foram ajustadas funções de segundo grau, as quais apresentaram coeficientes de determinação igual a 0,$99 ; 0,99$ e 0,90 , respectivamente (Figura 22).

Nas três profundidades, notou-se a redução da produtividade em função da diminuição dos valores de potencial matricial de água no solo. $\mathrm{Na}$ profundidade de $0,30 \mathrm{~m}$ foi onde se concentrou maior volume de raízes. Nesta profundidade, a menor produtividade foi de 80

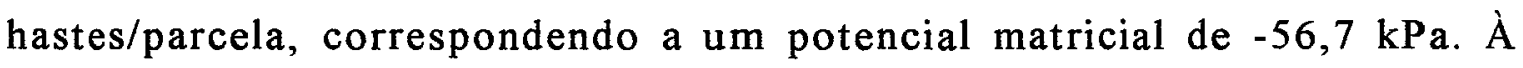
partir deste ponto, as produtividades foram maiores, ocorrendo um aumento do potencial matricial de água no solo, chegando à $-6,2 \mathrm{kPa}$, e uma produtividade de 146 hastes/parcela para o tratamento T125 (Tabela $10)$.

Com os resultados obtidos neste trabalho, com duração de dois meses, observou-se que as plantas não sofreram estresse hídrico, mesmo no tratamento $\mathrm{T} 25$, mas apresentaram redução no IAF e na produtividade. Chimonidou-Pavlidou (1998), estudando o efeito de quatro freqüencias de irrigação, verificou que a leitura mínima de potencial matricial foi de $-52,0 \mathrm{kPa}$ concluindo que as plantas não sofreram estresse hídrico neste potencial. Plaut et al. (1976), estudando a produtividade da roseira obteve máxima produção quando o potencial matricial de água no solo não excedeu $-6,0 \mathrm{kPa}$. 


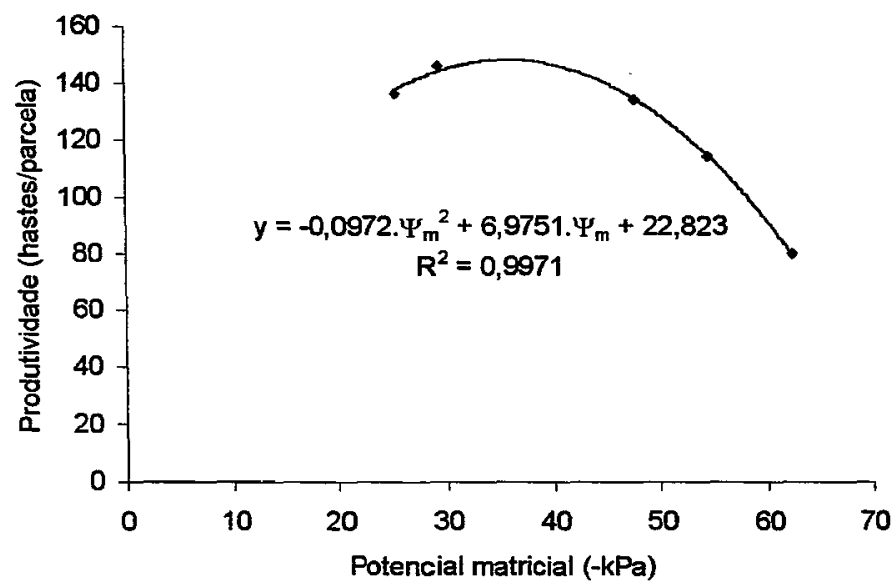

(a)

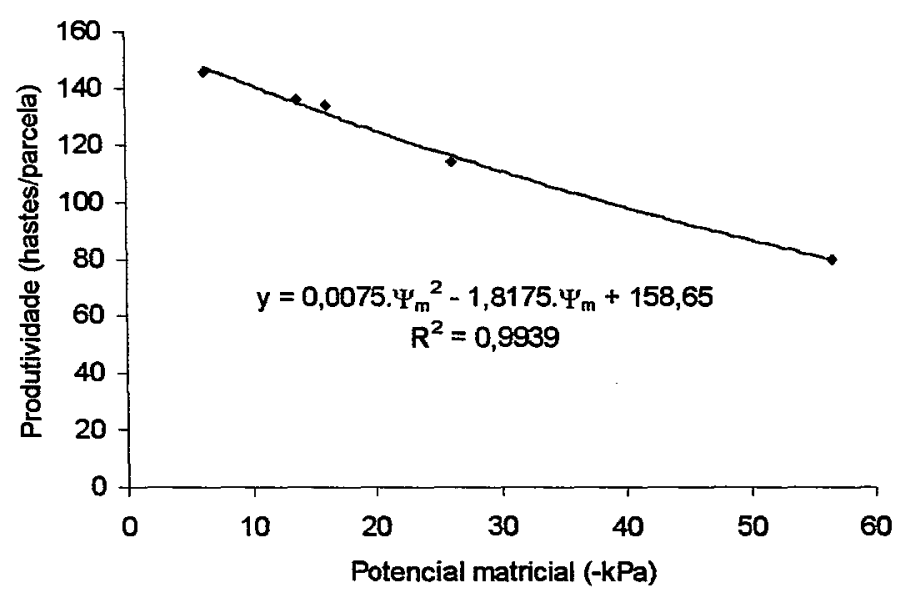

(b)



(c)

Figura 22. Produtividade da roseira em função do potencial matricial para as profundidades $0,10 \mathrm{~m}$ (a), $0,30 \mathrm{~m}$ (b) $\mathrm{e} 0,50 \mathrm{~m}$ (c). 


\section{CONCLUSÕES}

De acordo com os resultados obtidos neste trabalho pode-se concluir que:

- Não houve diferença significativa entre os tratamentos para os parâmetros avaliados, comprimento e diâmetro das hastes, comprimento, diâmetro, massa fresca e massa seca dos botões florais e índice de área foliar, entretanto os valores médios observados em cada parâmetro aumentaram de acordo com o aumento das lâminas de irrigação aplicadas, apresentando maior qualidade das hastes e botões florais.

- Os tratamentos T75, T100 e T125 apresentaram aumentos na produtividade de 67,$5 ; 70,0$ e $82,5 \%$, respectivamente, em relação ao tratamento $\mathrm{T} 25$. O tratamento $\mathrm{T} 125$ obteve uma produtividade de $17.033 \mathrm{dz} / \mathrm{ha}$, enquanto que o tratamento T25 obteve 9.333 $\mathrm{dz} / \mathrm{ha}$, resultando em um aumento na produtividade $\mathrm{de} 7.700 \mathrm{dz} / \mathrm{ha}$. 


\section{CONSIDERAÇÕES FINAIS}

Trabalhos futuros envolvendo aplicação de lâminas de irrigação devem ser planejados, permitindo um período maior de avaliação e assim definir uma metodologia eficaz para determinar as fases críticas da cultura em relação a demanda hídrica.

A produção comercial de rosas sob ambiente protegido vem crescendo no Brasil, principalmente nos municípios de Atibia (SP), Holambra (SP) e Andradas (MG). Neste sentido, pesquisas sobre ambiência, necessidade de água pela cultura, nutrição mineral e fertirrigação devem ser incentivadas a fim de auxiliar o produtor

brasileiro a obter maior qualidade $e$ produtividade das hastes, conseguindo desta forma, maior aceitação no mercado interno e aumento na exportação. 


\section{REFERÊNCIAS BIBLIOGRÁFICAS}

AGBARIA, H.; HEUER, B.; ZIESLIN, N. Effects of grafting on transpiration, $\mathrm{CO}_{2}$ fixation and growth of rose plants (Rosa hybrida cvs. Ilseta and Mercedes). The Journal of Horticultural Science, v.70, n.4, p.651-656, 1995.

ANGELOCCI, L.R. Estimativa da evapotranspiração máxima de macieiras (Malus spp.) em pomares pelo modelo de Penman Monteith. Piracicaba, 1996. 103p. Tese (Livre Docência) - Escola Superior de Agricultura "Luiz de Queiroz", Universidade de São Paulo.

ALVES, D.R.B.; KLAR, A.E. Comparação de métodos para estimar evapotranspiração de referência em túnel de plástico. Irriga, v.1, n.2, p.26-34, 1996.

ARRUDA, S.T.; OLIVETTE, M.P.A.; CASTRO, C.E.F. Diagnóstico da floricultura do Estado de São Paulo. Revista Brasileira de Horticultura Ornamental, v.2, n.2, p.1-18, 1996.

BAILLE, M.; BAILLE, A.; DELMON, D. Microclimate and transpiration of greenhouse rose crops. Agricultural and Forest Meteorology, n. 71, p.83-97, 1994.

BAILlE, M.; LAURY, J.; BAILLE, A. Some comparative results on evapotranspiration of greenhouse ornamental crops, using lysimeters, grrenhouse $\mathrm{H}_{2} \mathrm{O}$ balance and LVTD sensors. Acta Horticulturae, n.304, p.199-208, 1992. 
BAKKER, J.C. Measurement of canopy transpiration or evapotranspiration in grrenhouse by means of sample vapour balance model. Agricultural and Forest Meteorology, n.37, p.133-141, 1986.

BAILEY, B.J. Microclimate, physical processes and greenhouse technology. Acta Horticulturae, n.174, p.35-42, 1985.

BAÑON ARIAS, S.; CIFUENTES ROMO, D.; HERNANDEZ, J.A.F.; BENEVENTE-GARCIA, A. La Rosa. In: BAÑON ARIAS, S.; CIFUENTES ROMO, D.; HERNANDEZ, J.A.F.; BENEVENTEGARCIA, A. (Ed.) Gerbera, Lilium, Tulipán y Rosa. Madrid: Mundi-Prensa, 1993. cap.4, p.202-250.

BOZARTH, C.S.; KENNEDY, R.A.; SCHEKEL, K.A. The effects of leaf age on photosynthesis in rose. Journal of Americam Society of Horticultural Science, v.107, n.5, p.133-141, 1986.

BOULARD, T.; JEMA, R. Greenhouse tomato crop transpiration model aplication to irrigation control. Acta Horticulturae, n.335, p.381$387,1993$.

CABALLERO, M.; MANSITO, P.; ZIESLIN, N. Water use and crop productivity of roses growing on volcanic lapilli (Picon) in Canary Islands. Acta Horticulturae, n.424, p.41-44, 1996.

DE GRAF, R.; VAN DEN ENDE, J. Transpiration of the glasshouse crops. Acta Horiculturae, n.119, p.147-158, 1981.

DOORENBOS, J.; PRUITT, W.O. Necessidades hídricas das culturas. Trad. De H.R. Gheyi, J.E.C. Metri e F.A.V. Damasceno. Campina Grande:UFPB, 1997. 204p.

FARIAS, J.R.B.; BERGAMASCHI, H:; MARTINS, S.R. Evapotranspiração no interior de estufas plásticas. Revista Brasileira de Agrometeorologia, v.2, p.17-22, 1994. 
GISLERÖD, H.R.; SELMER-OLSEN, A.R.; MORTENSEN, L.M. The effect of air humidity on nutrient uptake of some greenhouse plants. Plant and Soil, n.102, p.193-196, 1987.

GOLDBERG, D.; GORNAT, B.; BAR, Y. The distribution of roots, water and minerals as a result of trickle irrigation. Journal American of Horticultural Science. v.96, n.5, p.645-648, 1971.

STANHILL, G.; VAADIA, Y. Factors affecting plant responses to soil water. In: HAGAN, R.M.; HAISE, H.R.; EDMINSTER, T.W. Irrigation of agricultural lands. Madison: American Society of Agronomy, 1967. cap.23, p.446-457.

HAND, D.W. Effects of atmospheric humidity on greenhouse crops. Acta Horticulturae, n.229, p.143-158, 1988.

HERNANDEZ, F.B.T. Manejo da irrigação em fruteiras. http://www.agr.feis.unesp.br/fruteiras. (14/11/1999)

INSTITUTO BRASILEIRO DE FLORICULTURA. Boletim Ibraflor. Campinas: IBRAFLOR, 1997. 96p.

KÄMPF, A.N. A floricultura brasileira em números. Revista Brasileira de Horticultura Hornamental, v.3, n.1, p. 1-7, 1997.

KLAR, A.E. Irrigação: frequência e quantidade de aplicação. São Paulo: Nobel, 1991. 156p.

MARTINELLI, D.; VILLA NOVA, N.A. Utilização do tanque "Classe A" e do evaporímetro de "Piche" na otimização dos métodos de Penman e Thornthwaite. In: CONGRESSO BRASILEIRO DE AGROMETEOROLOGIA, Maceió, 1989. Anais. Maceió: Sociedade Brasileira de Agrometeorologia, 1989. p.256-264.

MARTINEZ GARCIA, P.F. Características climaticas de los invernaderos de plástico. Madrid: Instituto Nacional de Investigaciones AgrariasINIA, 48p., Hoja Tecnica, n.19, 1978.

MARTINEZ GARCIA, P.F. La regulación de Las condidiones del ambiente en los cultivos protegidos. In: FEIRA TECNICA 
INTERNACIONAL DE LA MAQUINARIA AGRICOLA, 1986. Zaragoza: Associación Nacional de Ingenieros Agrónomos, 1986. p.135-147.

MASTALERZ, J.W. Environmental factors light, temperature, and carbon dioxide. In: LANGHANS, R.W. Roses: A manual on the culture, management, diseases and insects of greenhouse roses. New York: Roses Incorporated, 1987. cap15, p.147-170.

MEDEIROS, J.F.; PEREIRA, F.A.C.; FOLEGATTI, M.V.; PEREIRA, A.R.; VILLA NOVA, N.A. Comparação entre evaporação em tanque classe A padrão e em minitanque, instalados em estufa e estação meteorológica. In: CONGRESSO BRASILEIRO DE AGrometeorologia, Piracicaba, 1997. Anais. Piracicaba: Sociedade Brasileira de Agrometeorologia, 1997. p..228-230.

MORESHET, S.; PLAUT, Z.; ZIESLIN, N. Spatial variation in glasshouse rose flower production in relation to solar radiation. Scientia Horticulturae, n.5, p.269-276, 1976.

MOE, R. Growth and flowering in roses. Acta Horticulturae, n.218, p.121-130, 1988.

MAÑAS, F.M.S.O; DE JUAN VALERO, J.A. Agronomia de riego. Madrid: Mundi-Prensa, 1993. 732p.

PASIAN, C.C.; LIETH, J.H. Analysis of the response of net photosynthesis of rose leaves of varying ages to photosinthetic active radiation and temperature. Journal of American Society of Horticultural Science, v.144, n.4, p.581-586, 1989.

PEREIRA, A.B.; CARVAlHo, L.R.; FONSECA, L.B. Programa para análise de estimativa da evapotranspiração potencial, empregados em estudos de avaliação de consumo hídrico de culturas irrigadas. Engenharia Rural, v.5, n.2, p.49-60, 1994.

PEREIRA, A.R.; VILlA NOVA, N.A.; SEDIYAMA, G.C. Evapo(transpi)ração. Piracicaba: FEALQ, 1997. 183p. 
PIZARRO, F.C. Riegos localizados de alta frecuencia: goteo, microaspersion, exudacion. 3.ed. Madrid: Mundi-Prensa, 1996. $513 \mathrm{p}$.

POST, K.; HOWLAND, J.E. Influence of nitrate level and light intensity on the growth and production of greenhouse roses. Proceedings of American Society Horticultural Science. v.47, p.446-450, 1946.

PRADOS, N.C. Contribución al estudio de los cultivos enarenados en Almeria: Necessidades hídricas y extración del nutriente del cultivo de tomate de crescimento indeterminado en abrigo de polietileno. Almeria, 1986. 195p. Tese (Doutorado), Caja Rural Provincial, Almeria .

PLAUT, Z.; ZIESLIN, N. The effect of canopy wetting on plant water status, $\mathrm{CO}_{2}$ fixation, ion content and growth rate of 'Baccara' roses. Physiologia Plantarum, n.39, p.317-322, 1977.

ROBLEDO, F.P.; MARTIN, L.V. Aplicación de los plásticos en la agricultura. Madrid: Mundi Prensa, 1981. 52p.

SALINGER, J.P. Rosas de invernadero. In:SALINGER, J.P. Producción comercial de flores. Zaragoza: Acribia, 1991. cap.4, p.279-294.

SHANKS, J.B.; LAURIE, A. A progress report of some rose root studies. Proceedings of the American Society for Horticultural Science, n.53, p.473-488, 1949.

STONE, L.F.; SILVEIRA, P.M. Determinação da evapotranspiração para fins de irrigação. Goiânia: EMBRAPA/CNPAF, 1995. 49p.

TANAKA, M.; GENTA, H. Control del medio ambiente bajo invernadero y tunel plastico. Salto: Estacion Experimental del Citricultura, 1982. $61 \mathrm{p}$.

TAPIA, G.J. Filmes termicos para invernaderos. Revista de los Plasticos Modernos, v.295, p.75-82, 1981. 
URBAN, L. Effect of high-pressure mist and daytime continuous $\mathrm{CO} 2$ enrichment on leaf difusive conductance of Rosa hybrida plants growth on rockwool. Acta Horticulturae, n.361, p.317-324, 1994.

URCULLU, G.B. Cultivos ornamentales para flor cortada: Cultivo del rosal. Barcelona: Salvat, 1953. 512p.

VOLPE, C.A.; BOUHID ANDRÉ, R.G.; VALARELlI, P. Comparação da evaporação medida em diferentes evaporímetros e em tanque padrão $\left(20 \mathrm{~m}^{2}\right) . I n: C O N G R E S S O$ BRASILEIRO DE AGROMETEOROLOGIA, Campinas, 1996. Anais. Campinas: Sociedade Brasileira de Agrometeorologia, 1996. p.191-203.

WHITE, J.W.; HOLCOMB, E.J. Water requirement and irrigation practices. In: WHITE, J.W.; HOLCOMB, E.J. A manual of greenhouse rose production. Ithaca: Roses incorporated, 1987, 375p. WITHERS, B.; VIPOND, S. Irrigation: design and practice. London: B. T. Batsford. 1974. 306p.

WRIGHT, J.L. New evaporation crop coeffients. Journal of Irrigation and Drainage Division, v. 108, p.57-74, 1982. 


\section{APÊNDICE}


Tabela 11. Quadro de análise de variança e regressão para comprimento das hastes florais.

\begin{tabular}{lcccc}
\hline Causas da Variação & G.L. & S.Q. & Q. M. & PROB.>F \\
\hline Blocos & 4 & 90,2150471 & & \\
Lâmina & $(4)$ & 218,746142 & 54,6865355 & 0,00018 \\
Regressão Linear & 1 & 184,3200 & 184,3200 & 0,00004 \\
Regressão Quadr. & 1 & 5,3655279 & 5,3655279 & 0,27999 \\
Desvios da Regr. & 2 & 29,0688559 & 14,534428 & 0,05834 \\
Resíduo & 16 & 68,7168103 & 4,2948006 & \\
\hline Total & 24 & & & \\
\hline
\end{tabular}

Tabela 12. Quadro de análise de variança e regressão para diâmetro das hastes florais.

\begin{tabular}{lcccc}
\hline Causas da Variação & G.L. & S.Q. & Q. M. & PROB.>F \\
\hline Blocos & 4 & 0,255699 & & \\
Lâmina & $(4)$ & 1,056924 & 0,264231 & 0,03459 \\
Regressão Linear & 1 & 0,712818 & 0,712818 & 0,00807 \\
Regressão Quadr. & 1 & 0,322321 & 0,322321 & 0,05689 \\
Desvios da Regr. & 2 & 0,021796 & 0,010898 & 0,87104 \\
Resíduo & 16 & 1,253232 & 0,078327 & \\
\hline Total & 24 & & & \\
\hline
\end{tabular}


Tabela 13. Quadro de análise de variança e regressão para comprimento dos botões.

\begin{tabular}{lcccc}
\hline Causas da Variação & G.L. & S.Q. & Q. M. & PROB.>F \\
\hline Blocos & 4 & 0,106751 & & \\
Lâmina & $(4)$ & 0,258592 & 0,0646482 & 0,02263 \\
Regressão Linear & 1 & 0,224450 & 0,2244501 & 0,00246 \\
Regressão Quadr. & 1 & 0,002401 & 0,0024014 & 0,71164 \\
Desvios da Regr. & 2 & 0,031732 & 0,0158663 & 0,58617 \\
Resíduo & 16 & 0,270239 & 0,01689 & \\
\hline Total & 24 & 0,635583 & & \\
\hline
\end{tabular}

Tabela 14. Quadro de análise de variança e regressão para diâmetro dos botões.

\begin{tabular}{lcccc}
\hline Causas da Variação & G.L. & S.Q. & Q. M. & PROB.>F \\
\hline Blocos & 4 & 7,5889884 & & \\
Lâmina & $(4)$ & 6,6669829 & 1,6667457 & 0,32134 \\
Regressão Linear & 1 & 5,8004172 & 5,8004172 & 0,04912 \\
Regressão Quadr. & 1 & 0,0697742 & 0,0697742 & 0,81482 \\
Desvios da Regr. & 2 & 0,7964942 & 0,3982471 & 0,74554 \\
Resíduo & 16 & 20,9538412 & 1,3096151 & \\
\hline Total & 24 & 35,2098125 & & \\
\hline
\end{tabular}


Tabela 15. Quadro de análise de variança e regressão para massa fresca dos botões.

\begin{tabular}{lcccc}
\hline Causas da Variação & G.L. & S.Q. & Q. M. & PROB.>F \\
\hline Blocos & 4 & 2,0791778 & & \\
Lâmina & $(4)$ & 3,8441799 & 0,9610450 & 0,04675 \\
Regressão Linear & 1 & 3,1200047 & 3,1200047 & 0,00618 \\
Regressão Quadr. & 1 & 0,0499563 & 0,0499563 & 0,69660 \\
Desvios da Regr. & 2 & 0,6741473 & 0,3370736 & 0,36599 \\
Resíduo & 16 & 5,0166259 & 0,3135391 & \\
\hline Total & 24 & 10,939983 & & \\
\hline
\end{tabular}

Tabela 16. Quadro de análise de variança e regressão para massa seca dos botões.

\begin{tabular}{lcccc}
\hline Causas da Variação & G.L. & S.Q. & Q. M. & PROB.>F \\
\hline Blocos & 4 & 0,0101136 & & \\
Lâmina & $(4)$ & 0,0376817 & 0,0094204 & 0,20347 \\
Regressão Linear & 1 & 0,0264500 & 0,0264500 & 0,04316 \\
Regressão Quadr. & 1 & 0,0001157 & 0,0001157 & 0,88239 \\
Desvios da Regr. & 2 & 0,0111143 & 0,0055572 & 0,60482 \\
Resíduo & 16 & 0,0898047 & 0,0056128 & \\
\hline Total & 24 & 0,1376000 & & \\
\hline
\end{tabular}

